\title{
Turen går til Second Life - Tips til dig, der planlægger et besøg til den virtuelle verden
}

\section{Inger-Marie F. Christensen}

Cand. Mag og Master i lkt og læring

E-læringskoordinator, Syddansk Universitet.

Avatarnavn: Inga Miles

Artiklen indeholder bidrag fra Anders Quitzau og Anja P. Nielsen,

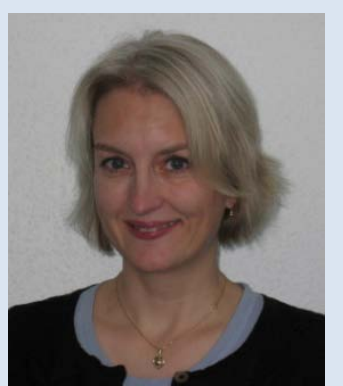
IBM, Tony Breindal fra Det Nationale VidenCenter for e-Læring, Marianne Riis, PHD stipendiat fra Aalborg Universitet, Inge Knudsen fra Horsens Handelsskole, Signý Óskarsdóttir fra Bifröst Universitet på Island. En varm tak til jer alle for jeres store engagement i Second Life og for jeres villighed til at erfaringsudveksle og videndele.

Forfatteren er ansat i Udviklingssekretariatet for e-læring under Kompetenceområdet på Syddansk Universitet. Udviklingssekretariatet yder teknisk support og pædagogisk sparring om netbaseret kommunikation, samarbejde og læring til undervisere og administrativt ansatte på SDU. Forfatteren har haft sin gang i Second Life siden juni 2007 og arbejder nu aktivt for at udbrede kendskabet til og anvendelsen af Second Life blandt underviserne på SDU. 


\section{Indledning}

Formålet med denne artikel er at give et overblik over Second Life for at gøre det lettere for især nybegyndere at orientere sig og planlægge mere målrettede og dermed succesfulde besøg in-world. Artiklen vil derfor ikke gå i dybden med de emner, der tages op, men i stedet ganske kort forsyne læseren med en indledende begrebsafklaring, fakta, praktiske oplysninger og links til yderligere information. Sidste del af artiklen indeholder slurls til og beskrivelser af interessant steder i Second Life, som er et besøg værd. Denne del af artiklen var ikke blevet til uden anbefalinger fra en række erfarne og dedikerede Second Life brugere, som velvilligt har delt deres viden og erfaringer med mig og LOMs læsere. En stor tak til:

Anders Quitzau og Anja P. Nielsen, IBM, Tony Breindal fra Det Nationale VidenCenter for e-Læring, Marianne Riis, PHD stipendiat fra Aalborg Universitet, Inge Knudsen fra Horsens Handelsskole og Signý Óskarsdóttir fra Bifröst Universitet på Island.

\section{Hvad er Second Life?}

Second Life er en 3D virtuel verden, også kaldet et metaverse. På Wikipedia defineres metaverse således:

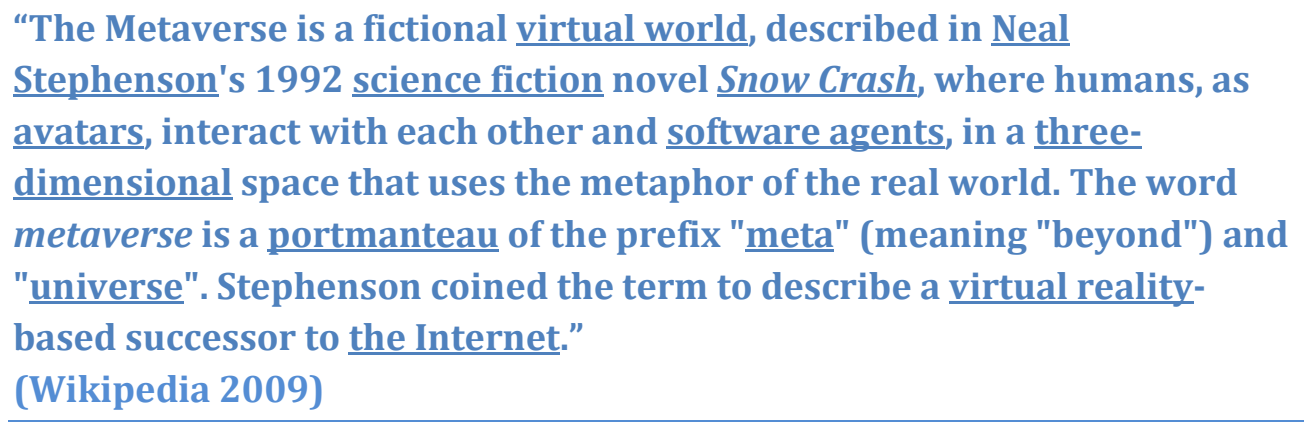

Du får adgang til Second Life online via nettet. Det er Linden Lab ${ }^{1}$, der står bag, og de fortæller følgende om deres mission: "It is our mission to connect us all to an online world that advances the human condition" (Linden Lab 2009).

Second Life består af regioner også kaldet øer. I 3. kvartal 2009 var der 23.566 privatejede regioner eller øer i Second Life (Second Life blog 2009). I september 2009 var der 750.446 personer, der jævnligt loggede på (Second Life blog 2009).

\footnotetext{
${ }^{1}$ Linden Lab blev grundlagt af Philip Rosedale i 1999. Hovedkvarteret ligger i San Francisco, USA (Linden Lab 2009).
} 
Ofte hører man bemærkningen Second Life Grid, der refererer til det netværk af servere, der simulerer regionerne i den virtuelle verden. Der er også et Teen Grid til rådighed for de 13 til 17 årige.

Læs om Second Life’s historie online i Wired Magazine (Wired 2006).

\section{Sådan kommer du til Second Life}

Et vellykket besøg i Second Life starter med en god computer, der er egnet til spilbrug og således har grafikkortet i orden. Second Life kører særlig godt på Mac maskiner. På denne webside kan du se, hvilke krav, der stilles til en computer, der skal kunne køre Second Life: http://secondlife.com/support/system-requirements/.

I Second Life er brugeren, også kaldet indbyggeren (på engelsk resident) tilstede i form af en avatar, der er ens grafiske repræsentation i det virtuelle (se Morsi 2006 for en diskussion af avatar begrebet). Liboriussen argumenter dog for, at avataren ikke kun er en grafisk repræsentation, men også tilføjer en kropslig og tingslig dimension, der gør det muligt for brugeren at påvirke objekter i den virtuelle verden og dermed skaber grundlaget for interaktivitet (Liboriussen 2009).

\footnotetext{
"Brugerens forhold til avataren er kropligt funderet, og avataren er en slags ting, eller for at være lidt mere præcis, en form for dukke.

Fiktionsverdener forandrer sig over tid. Hvis den, som oplever en given fiktionsverden, har indflydelse på verdens gang er der tale om interaktivitet; et fænomen som computere er særdeles velegnede til at understøtte."

(Liboriussen 2009:16)
}

Det er således gennem avataren, at brugeren navigerer, kommunikerer og interagerer med andre avatarer og objekter in-world. For at blive klar til besøget skal du derfor oprette en avatar og installere Second Life på din computer. Det kan du gøre via websiden: http://secondlife.com. Klik på Join now i øverste, højre hjørne af skærmen. Herfra bliver du ledt igennem processen med dels at oprette en avatar og dels at installere Second Life på din compuer. Du skal som noget af det første vælge et navn til din avatar. Bemærk at du frit kan vælge fornavn, medens efternavnet skal vælges fra en liste. Vær omhyggelig med navngivningen af din avatar, da det vil følge dig under alle dine besøg in-world. Du har ikke mulighed for at ændre det.

Du skal også vælge udseende, men du kan løbende foretage ændringer. Se f.eks. denne video fra Youtube, der viser, hvordan du ændrer din avatars udseende: http://www.youtube.com/watch?v=VsS4IXI32 Y. 
Som nyfødt avatar kan du vælge mellem to destinationer. Du kan vælge Help Island, som din første destination. Her kan du lære om navigation og kommunikation i Second Life. Eller du kan vælge at hoppe direkte til en destination, der emnemæssigt har din interesse. Vælger du Help Island har du herfra mulighed for at teleportere til Second Life via opstillede tavler.

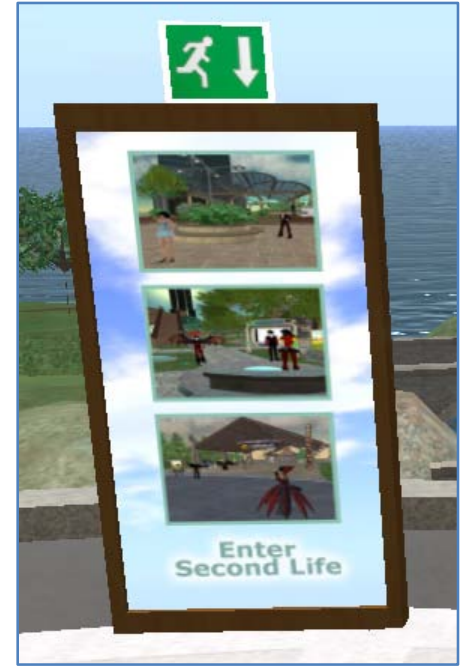

Figur 1. Teleport til Second Life fra Help Island.

\section{Påklædning}

I Second Life er der både mainstream og subkulturer. Du vil derfor møde mange forskellige udtryksformer og dress codes. De, der underviser eller driver virksomhed i Second Life er som oftest meget opmærksomme på, hvilke signaler, de sender både mht. udseende og påklædning. Mange vælger at klæde sig og bearbejde avatarens udseende, således at der er stor lighed ift. personens fremtræden i den virkelige verden.

\section{Kommunikationsformer}

Der er mange forskellige måder at kommunikere på i Second Life, der både giver mulighed for synkron og asynkron kommunikation. Asynkron kommunikation kan ske via notecards eller IM. Se denne video fra Youtube, der viser, hvordan man laver notecards in-world: http://www.youtube.com/watch?v=PwSIYGhZbT4. Notecards er et glimrende redskab, hvis man f.eks. gerne vil sende sine favorit landmarks til en ven eller gerne vil annoncere en begivenhed.

IM er private beskeder, du kan sende, selvom modtageren ikke er online. Modtageren får besked via mail om, at der er kommet en IM og kan logge på Second Life for at svare. Du sender en IM ved at klikke på Communicate knappen i nederste, venstre side af skærmen. Klik og markér den relevante avatar og klik derefter på IM knappen. Skriv din besked ind og klik på Send knappen. Du kan også fremsøge avatarer, du endnu ikke er venner med og sende en IM til dem. Det er nyttigt, hvis du f.eks. finder spændende steder i Second Life og gerne vil kontakte avataren, der står bag, for at høre mere om stedet. Synkron kommunikation kan foregå via chat, voice og gestik. Alle avartarer i nærheden kan se de chatbeskeder, du sender via Local Chat. Avatarer i 20 m omkreds kan høre, 
hvad du siger, når du bruger voice (Second Life Wiki Aug 2009). Klik på Talk knappen i nederste, højre hjørne af skærmen for at aktivere voice. Anvend et godt headset. Bemærk at Talk knappen fungerer som en walkie-talkie. Hold voice knappen nede, når du siger noget. Du har også mulighed for at klikke på Hængelåsen i venstre side af Talk knappen. Så kan du frit tale og alt, du siger, går igennem.

Du har mulighed for at skrue op og ned for andre avatarer, der ligeledes bruger voice. Klik på knappen med taleboblerne til venstre for Talk knappen. Klik og markér den avatar, hvis lyd, du gerne vil justere. Klik og træk lyden højere eller lavere nederst i "Active Speakers" boksen.

Din avatar kan også anvende kropssprog for at udtrykke humør og følelser. Klik på Gestures knappen i nederste, højre del af skærmen. Se også denne video fra Youtube om brug af gestik: http://www.youtube.com/watch?v=6WKo4G8aQBc.
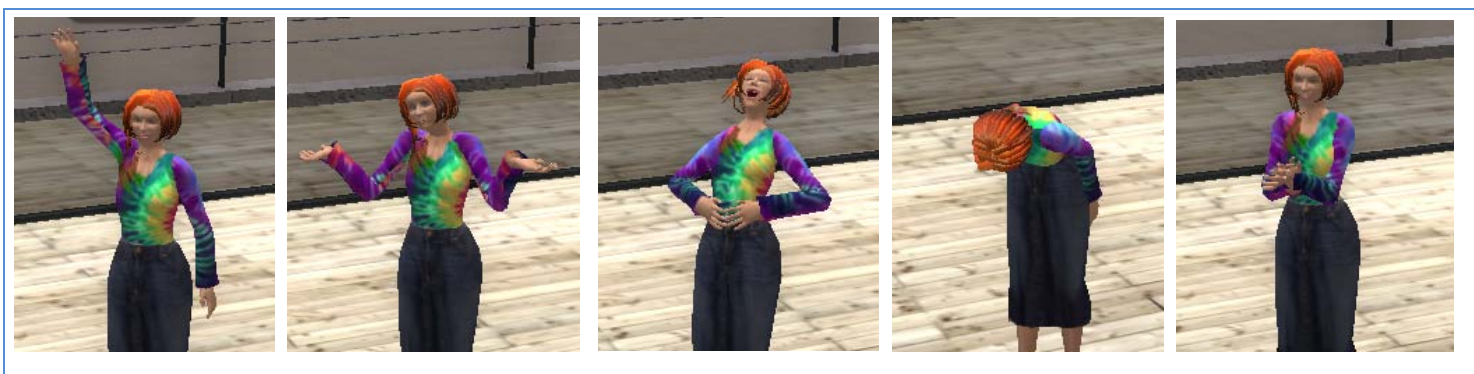

Figur 2. Anvendelse af gestik i Second Life. Vinke. Trække på skuldrene. En hjertelig latter. Et buk. Der klappes.

\section{Tidsforskel}

Ofte angives tidspunkter for arrangement in-world i SLT, dvs. Second Life tid. Du kan se det aktuelle tidspunkt i øverste, højre hjørne af skærmen. Det er samme tid som i Los Angeles, USA, der kører på PST (Pacific Standard Time). I Danmark er vi 9 timer foran Los Angeles/Second life. Dvs. at kl. 10.00 i Second life, er kl. 19.00 i Danmark. Det er således vigtigt at beregne tidsforskellen, så man møder op på rette tid, hvis man ønsker at deltage i et arrangement in-world.

På denne webside finder du et værktøj til hurtig beregning af tidsforskellen:

http://www.timeanddate.com/worldclock/converter.html. Først indtaster du dato og tidspunkt for det aktuelle arrangement. I øverste location vælges U.S.A - California - Los Angeles. I nederste location vælges Denmark - Copenhagen. Klik på Convert time knappen, og du får nu opgivet det danske tidspunkt for arrangementet. 
På grund af tidsforskellen vil du opleve, at nogle steder i Second Life virker øde. Det kan skyldes, at stederne er forladt, men det kan også skyldes, at vi, som ovenfor nævnt, er 9 timer foran SLT.

\section{Solopgang og solnedgang}

Det er altid nyttigt at vide, hvornår solen går op og ned på ens feriedestination. I Second Life bestemmer du selv. Klik på World i øverste menubar. Klik derefter på Environment Settings. Du kan nu selv vælge, hvor højt eller lavt solen skal stå på himlen. Flere steder i Second Life anbefaler, at man vælger solopgang eller solnedgang for at skabe en helt speciel stemning.

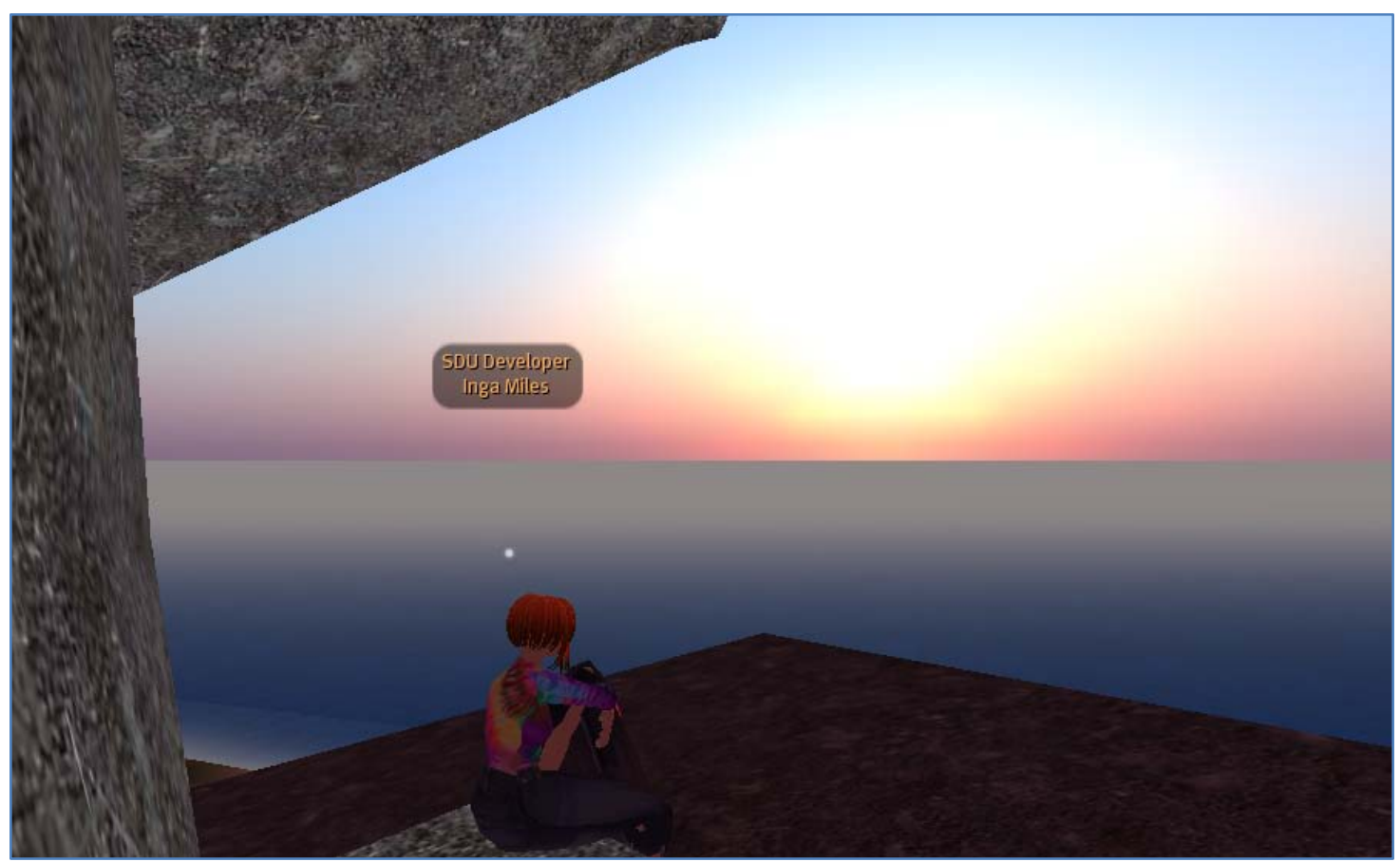

Figur 3. Solopgang ved Hanging Rock på SDUs ø Bifrost.

\section{Transport in-world}

I Second Life kan du, som i det virkelige liv, gå og løbe ved at anvende piletasterne. Du kan derudover, på ganske magisk vis, flyve og teleportere dig selv til nye steder eller sende en teleport til en ven og bringe ham/hende til din egen destination.

\section{Landmarks}

Teleports er ganske uundværlige, når du skal bevæge dig fra en region i Second Life til en anden. Når du besøger et nyt sted i Second Life, kan du oprette et landmark på stedet. Det fungerer i praksis som et bogmærke. Når du opretter et landmark, bliver det automatisk gemt i dit Inventory i en mappe med navnet "Landmarks", og du kan finde 
det frem og klikke på det, når du gerne vil besøge stedet igen. Se også denne video fra Youtube om teleporting: http://www.youtube.com/watch?v=bW2huyjuZB4.

Du opretter et landmark ved at placere dig på den relevante destination. Klik derefter på World i den horisontale menubar øverst. Klik derefter på Create Landmark Here.

Bemærk at du kan vælge og sætte bogmærke ved din "hjemmedestination". Det sker også under World. Vælg Set Home to Here.

\section{Teleports}

Ved at anvende søgefunktionen (Klik på Search knappen), kan du fremsøge interessante steder. Søgeresultaterne indeholder en teleport knap, sådan at du kan teleportere dig selv til stedet.

Du kan, som nævnt ovenfor, også sende en teleport til en ven og dermed "beame" vedkommende til din aktuelle destination. Det gør du ved at klikke på Communicate knappen i den nederste, horisontale menubar. Klik og markér den relevante avatar og klik derefter på Teleport knappen. Bemærk at du kun kan sende en teleport til venner, der er logget på Second Life.

\section{Flyv avatar flyv}

Også flyvefunktionen er ganske nyttig. Den er særlig anvendelig, når du er ankommet til en ny destination in-world og gerne vil danne dig et overblik over denne. Klik på Fly knappen i den nederste, horisontale menubar og bevæg dig vertikalt vha. page up og page down. Brug piletasterne for at flyve horisontalt. En elegant landing foretages ved at klikke page down indtil du igen står på jorden, og Fly knappen er inaktiv. Alternativt kan du klikke Stop flying, hvorved du med det samme ender på jorden igen.

\section{Slå benene op}

Din avatar har også mulighed for at sidde. Højreklik på stolen eller lign. og væg Sit here.

\section{Navigation}

Det kan være en prøvelse at bevæge sig rundt i Second Life i starten. Det er svært at manøvre uden om andre avatarer og objekter ved hjælp af piletasterne. De, der har erfaring fra computerspil har en klar fordel. Men her gælder det virkelig, at "øvelse gør mester".

Oplever du pludselig, at de andre avatarer er væk under et besøg i Second Life, så brug piletasterne og drej en omgang. Måske har de blot bevæget sig hen bag dig.

I Second Life vil du ofte få brug for at zoome ind på f.eks. bogsider, plancher og lignende, der er udstillet rundt omkring. Eller du er måske til et foredrag in-world og vil gerne kunne se foredragsholderens præsentation i den rigtige vinkel. Her kan du dels sørge for 
at få en god plads, dels kan du anvende Camera Controls, hvor du uafhængigt af din avatar kan justere din synsvinkel, sådan at du får alt med. Du finder Camera Controls under View i den øverste, horisontale menubar. Klik nu på pilene i Camera Controls boksen og på + eller minus for at justere din synsvinkel.

Brug også Map funktionen i Second Life, når du skal finde rundt på en ny location. Klik på Map knappen nederst til højre på skærmen.

Slurls

Hvis du gerne vil gøre opmærksom på en destination i Second Life på f.eks. din blog, hjemmeside eller i en mail, kan du indsætte/sende en slurl, dvs. en URL til en Second Life destination. Du laver en slurl ved at placere dig på den relevante destination i Second Life, derefter klikker du på Map knappen. Klik derefter på knappen Copy SLURL to clipboard i nederste, højre hjørne. Du kan nu kopiere din slurl og gøre den tilgængelig for andre.

\section{Ind byggerne, venner og grupper}

Det er vigtigt at tilbyde venskab til andre avaterer, man finder interessante og til bekendte, der ligeledes bebor Second Life. Man fremsøger andre avatarer og tilbyder dem venskab ved at klikke på Communicate knappen i den nederste, horisontale menubar. Klik derefter på Add. Indtast navnet på den avatar, du gerne vil tilbyde venskab. Klik og markér avatar navnet og klik derefter på Select. Denne avatar vil nu modtage dit tilbud om venskab og kan acceptere eller afslå. Via Communicate knappen kan man nu altid se, om ens venner er online og sende dem en IM eller en teleport.

I Second Life har du mulighed for at oprette en gruppe og invitere andre som medlemmer. Du kan også fremsøge relevante grupper og søge medlemskab af disse. Det er nyttigt, hvis man gerne vil holde sig ajour med arrangementer på et givent sted inworld.

Du fremsøger grupper ved at klikke på Search knappen nederst på skærmen. Klik derefter på fanen Groups. Indtast søgeord i søgeboksen, der befinder sig i øverste venstre hjørne af Groups boksen. Prøv at søge på WD Friend som er Wonderful Denmark gruppen. Klik på linket til gruppen for at se detaljer. Klik på knappen View Full Profile. Her har du adgang til en Join knap, hvis der er Open Enrollment. Bid mærke i, om det koster noget at blive medlem af gruppen.

Du etablerer selv en gruppe ved at klikke på Edit i menuen øverst på skærmen. Klik derefter på groups. Klik nu på Create knappen. Indtast navn mm. og sæt indstillinger for enrollment. Bemærk det koster 100 Linden\$ at lave en gruppe. 
Er du medlem af en gruppe, vil du kunne se gruppenavnet over dit avatarnavn, som befinder sig over din avatars hoved. Hvis du er medlem af flere grupper, får du brug for at kunne håndtere dine medlemskaber. Det sker ved at klikke på Edit. Klik derefter på Groups. Det gruppenavn du ser over dit avatarhoved er navnet på den gruppe, der er aktiveret. Hvis du ønsker at skifte navnet ud, skal du klikke på den gruppe, hvis navn, du gerne vil have vist. Klik derefter på Activate knappen. Ønsker du at forlade en gruppe, klikker du på gruppenavnet for at markere det og derefter på Leave.

\section{Valuta}

Valutaen i Second Life er Linden\$. Du kan sagtens bevæge dig rundt i Second life uden en øre på lommen, men som i det virkelige liv, er det sjovest at have penge at spendere. Der går ca. 250 Linden\$ på en U.S dollar. Du kan både købe og sælge Linden\$ på nettet, f.eks. via LindeX: http://secondlife.com/whatis/currency.php. Du kan anvende disse kreditkort til køb af Linden\$: Mastercard, Delta, Visa Electron, , Visa, American Express og JCB.

\section{Parlør}

Freebie Gratis tøj, hår osv.

Grid Et integreret system, der tilvejebringer et netværk af servere. Disse er oftest SIMs.

Holodeck Et holodeck gør det muligt at gemme et antal scenarier eller miljøer, (inklusive møbler mm.) på begrænset plads (Second Life Wiki Sep 2009). Indbyggeren kan rezze eller kalde et givent scenarie frem, alt efter, hvad der skal anvendes nu og her. Holodecks giver således en mere fleksibel udnyttelse af en region.

IM Instant message. En besked, du kan sende i Second Life til en anden avatar. Er modtageren ikke logget på, gemmes beskeden, og modtageren vil se den, næste gang, han eller hun logger på.

In-world I Second Life.

Inventory Din "rygsæk" i Second Life. I dit Inventory lagres alt, hvad du køber og skaber i Second Life, lige fra landmarks over notecards til tøj og sko. Klik på Inventory knappen nederst til højre på skærmen for at se dit Inventory.

IRL In real life. 
Lag Når Second Life fryser, og du ikke kan bevæge din avatar, oplever du lag. En løsning kan være at logge af og på igen.

Landmark En slags bogmærke, du kan "sætte" på en given destination. Ønsker du at vende tilbage til denne destination, kan du finde dine landmarks under Inventory. Klikker du på et af dine landmarks her, får du mulighed for at teleportere til denne destination.

Newbie Nybegynder.

Parcel Jordlod / parcel i Second Life.

Region Også kaldet ø.

Resident Bruger/indbygger i Second Life.

Rezze To rez eller rezze betyder at kalde et object frem i Second Life.

SIM Simulator. I betydningen SIM node, hvilket vil sige den fysiske server, der simulerer én eller flere regioner. Eller SIM processer. Dvs. processerne på de serverer, der simulerer regioner (Second Life Wiki 2008).

SL Kortform af Second Life, der ofte anvendes af brugerne.

Slurl En URL med koordinator til en destination i Second Life. SL+URL.

Teleport En teleport transporterer dig fra A til B i løbet af et sekund. Teleporting er en hurtig og behagelig måde at lade sig transportere på in-world.

Også kaldet region. Indbyggerne i Second Life kan købe en ø eller region og får dermed retten til at konstruere objekter på denne $\emptyset$.

\section{Nødhjælp}

I Second Life kan du hente hjælp fra mange kilder. Møder du en avatar med efternavnet Linden, er det en ansat fra Linden Lab, som du trygt kan henvende dig til. Eller søg hjælp under Help i den øverste, horisontale menubar. Herfra har du også adgang til den officelle Linden Blog. Det kan også anbefales at søge efter videoer på YouTube, hvor du finder et have af tutorials, der giver tips til kommunikation, navigation, konstruktion mm. i Second Life. 


\section{Inspiration - interessante steder at besøge}

Som altid når rejseforberedelserne er overstået, Second Life er installeret, avataren er rejseklar, man har styr på kommunikation og navigation in-world, melder spørgsmålet sig: Hvilke steder er interessant at besøge? Hvor er det, jeg kan opleve det virkelige Second Life, og ikke bare turistfælderne?

Vi har bedt erfarne Second Life brugere fra uddannelsesinstitutioner og virksomheder om at anbefale steder i Second Life, der er et besøg værd. Her er deres favorit slurls samt en kort beskrivelse af stedet, og hvorfor det er et besøg værd:

\section{Livets gang i Second Life}

Forfatteren anbefaler mindst et besøg til Wonderful Denmark, hvor der afholdes typiske danske arrangementer som Sct. Hans fest, valgmøder, fastelavnsfest mm. Her er der rig mulighed for at iagttage, hvordan det virtuelle liv udfolder sig og selv deltage i det omfang, man har tid og lyst. Bliv medlem af gruppen Wonderful DK, så får du automatisk besked, når der er nye arrangementer. Det er avataren Doctor Asp², der står bag Wonderful Denmark. Du kommer til torvet i Wonderful Denmark via denne slurl: http://slurl.com/secondlife/Wonderful\%20Denmark/132/137/22.

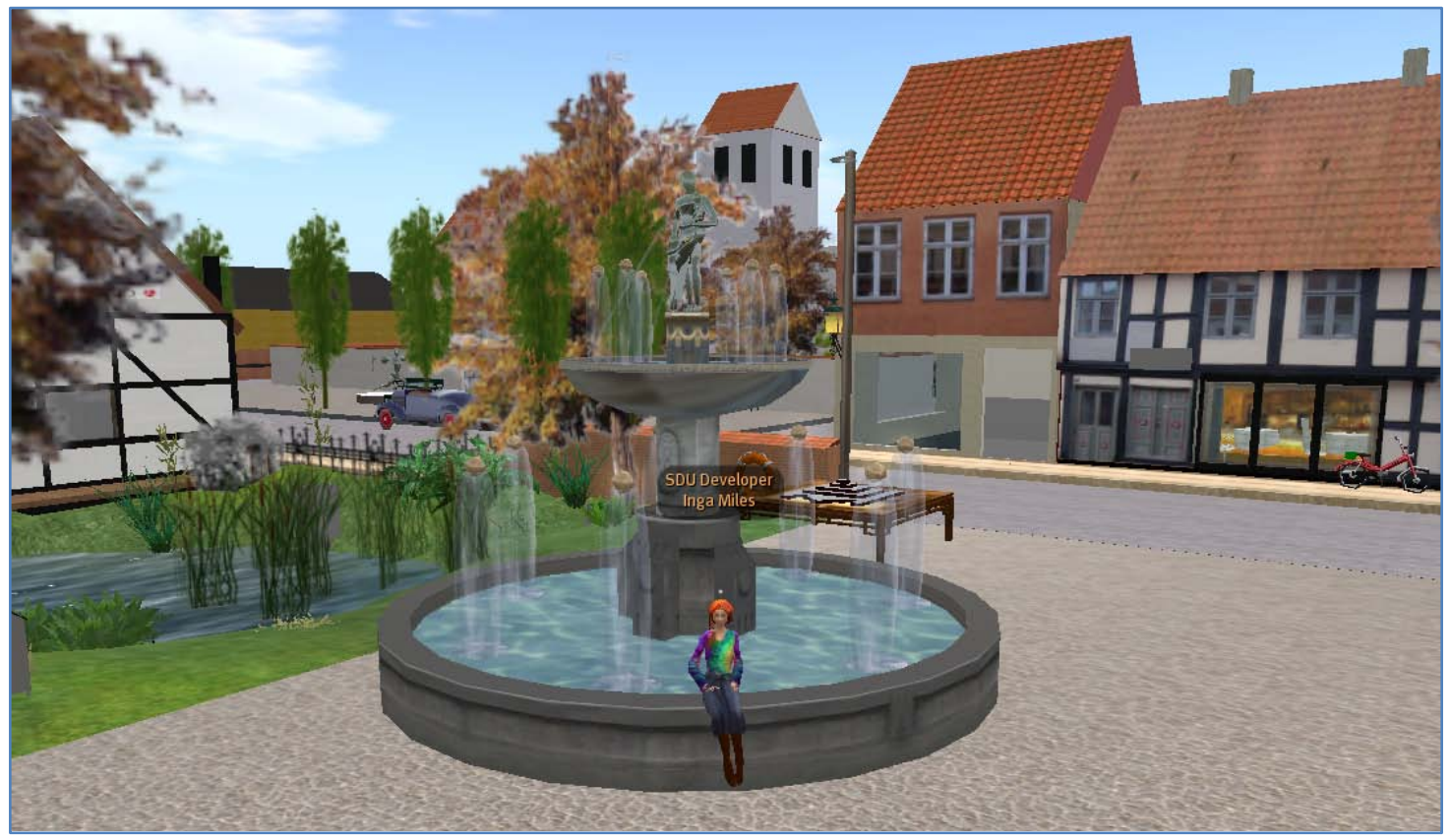

Figur 4. Torvet i Wonder Denmark.

2 Besøg Doctor Asps blog her: http://doctorasp.wordpress.com/. 
Historiens vingesus

Du har også mulighed for at dvæle ved historien på henholdsvis Historiens Hus og Vikingelandsbyen. Her kan du besøge Vikingecenteret:

http://slurl.com/secondlife/WD2/198/47/23 med både langhuse og vikingeskibe.

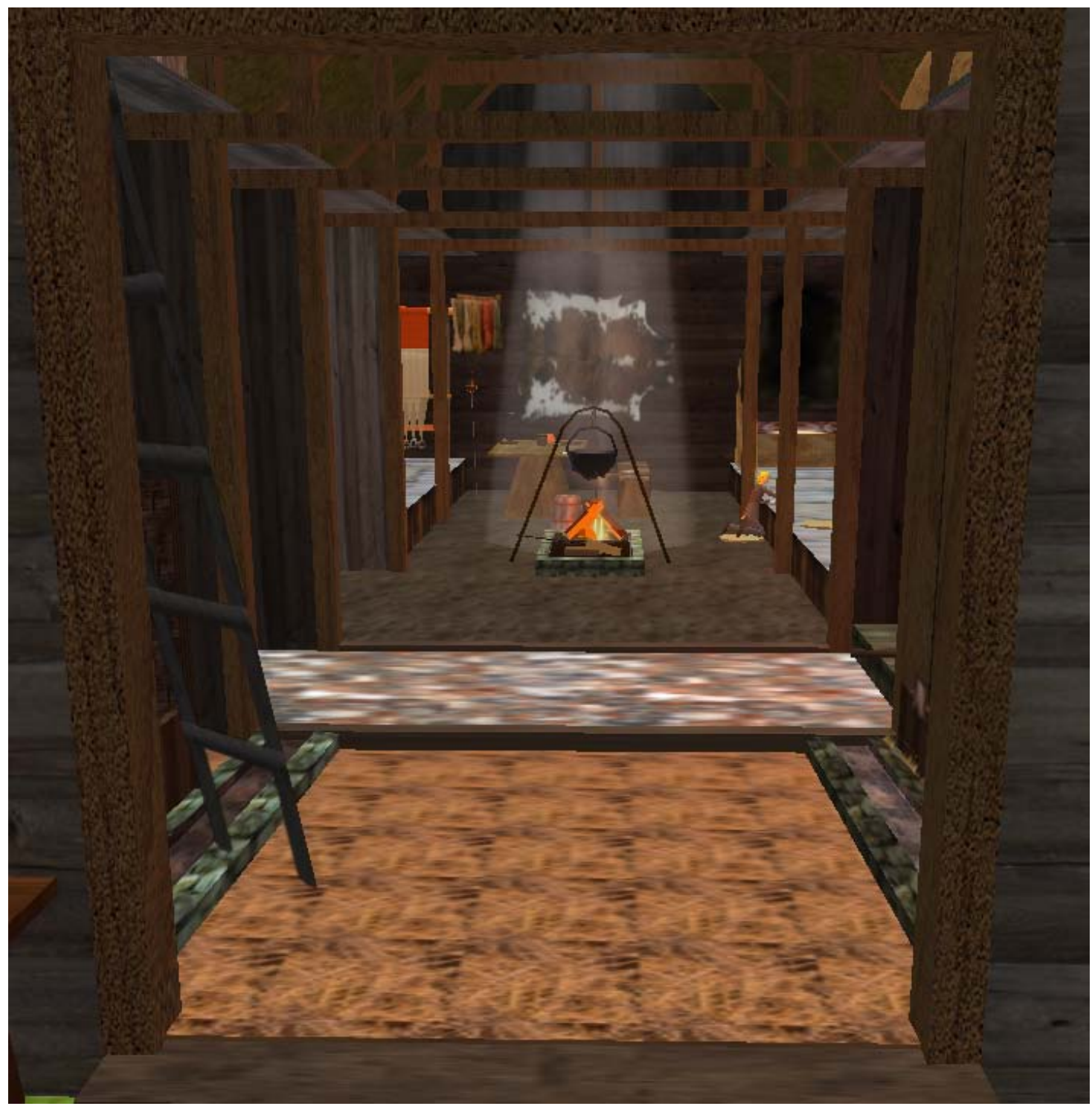

Figur 5. Et kig ind i et langhus på Vikingecentret.

Her har du slurlen til Historiens hus, hvor der er skiftende historiske udstillinger: http://slurl.com/secondlife/WD2/188/178/27. Den aktuelle udstilling viser bl.a. kropskunst i et historisk perspektiv. 


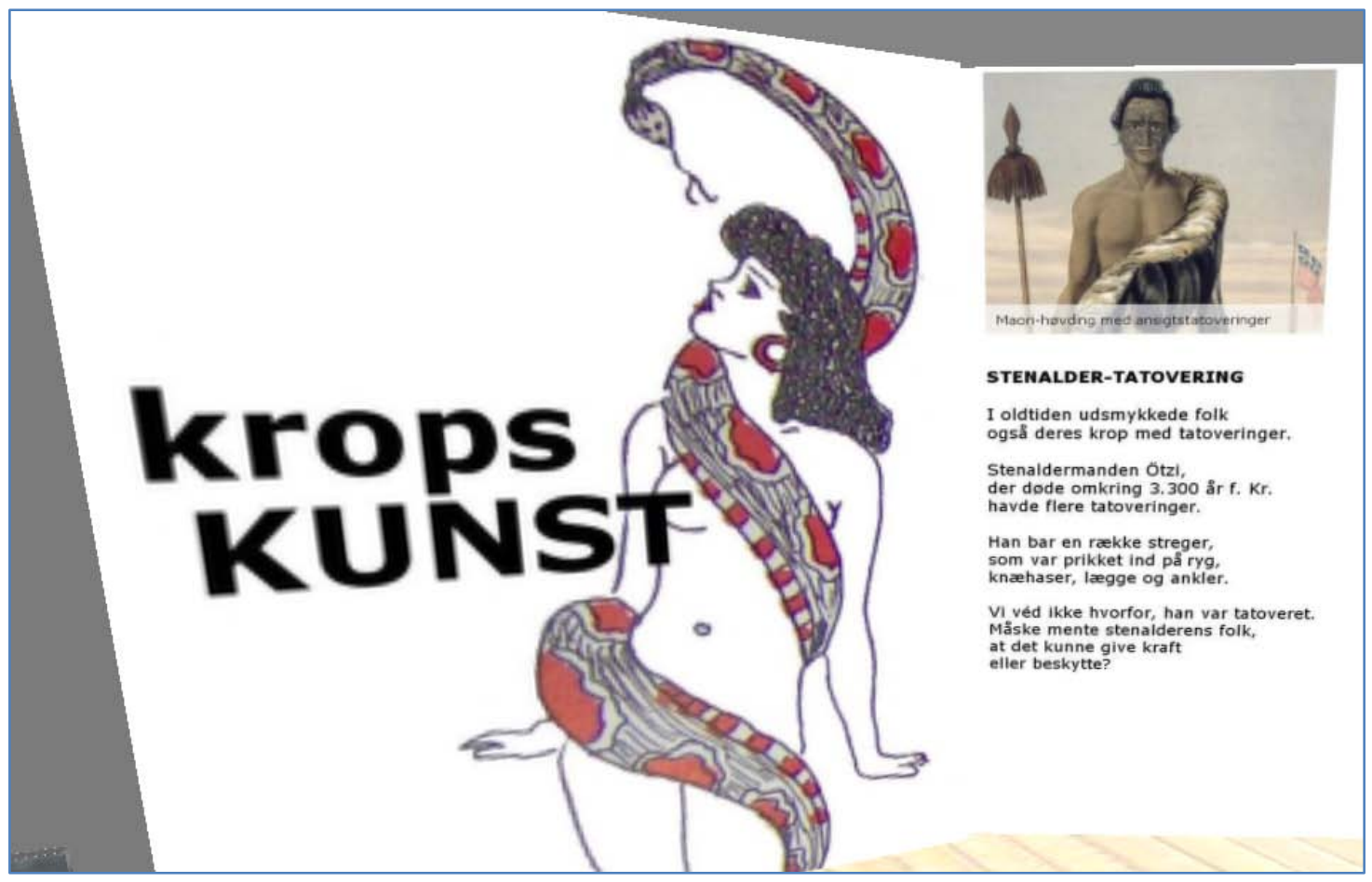

Figur 6. Udstilling på Historiens Hus, november 2009.

Historiens hus har desuden en fantastisk freebie shop, hvor du får gratis kan erhverve parykker og historiske påklædninger. Charlotta Jenkins ${ }^{3}$ er avataren bag.

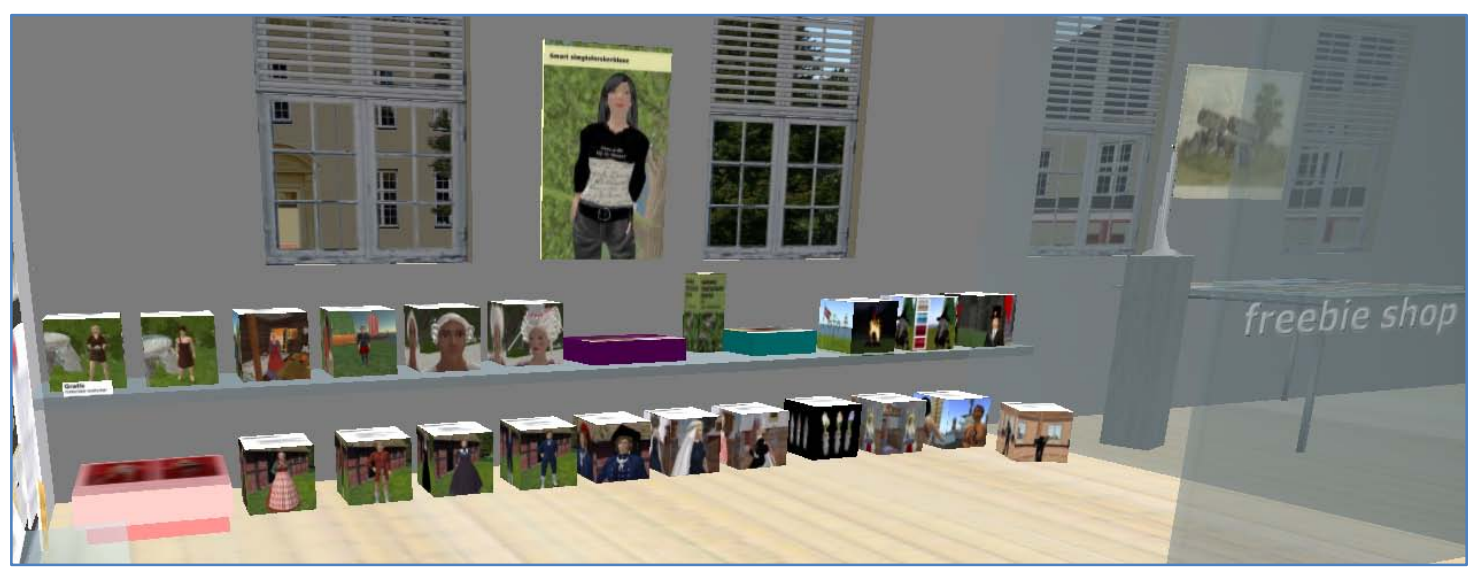

Figur 7. Freebie shop på Historiens Hus.

${ }^{3}$ Besøg Charlottas blog her: http://charlotteshj.wordpress.com/. 


\section{Wie geht's?}

Trænger du til at få børstet dit tyske af, kan du gøre det på Goethe Instituttet, der har virtuelle kurser hver tirsdag fra 7 -8 om morgenen SLT. Der er også "Deuthsch-LearnTreff" mandag til fredag fra 8-9 om morgenen SLT og hver Søndag kl. 11 - 12 i Caféen. Dette er kun et par af de mange tilbud, der møder dig på denne slurl:

http://slurl.com/secondlife/Goethe\%20Institut/78/139/25 Studér plancherne med oplysninger om arrangement og tidspunkt. Planchen indeholder desuden en teleport knap, der beamer dig til rette sted.

\section{Besøg IBM i Second Life og bliv klar til klimatopmøde}

Anja P. Nielsen, der er Life Cycle Manager for IBM DK Virtual Worlds og hendes kollega Anders Quitzau, der er Innovation Executive, Chief Technologist for iBM Innovation Network, Denmark anbefaler disse to slurls:

Anja og Anders favoritsted nr. 1 er IBMs "Virtual Green Data Center", som ligger her: http://slurl.com/secondlife/IBM\%20Business\%20Center2/207/28/33.

Anja fortæller:

\footnotetext{
"Denne lokation tilbyder information om IBM Services for grønne data centre på en rigtig god måde. Det giver også besøgende mulighed for at lære, hvordan IBM kan hjælpe med at håndtere og forbedre energi effektiviteten. Netop nu med Klimakonferencen lige om hjørnet, er det særlig aktuelt. "

(Nielsen 2009)
} 


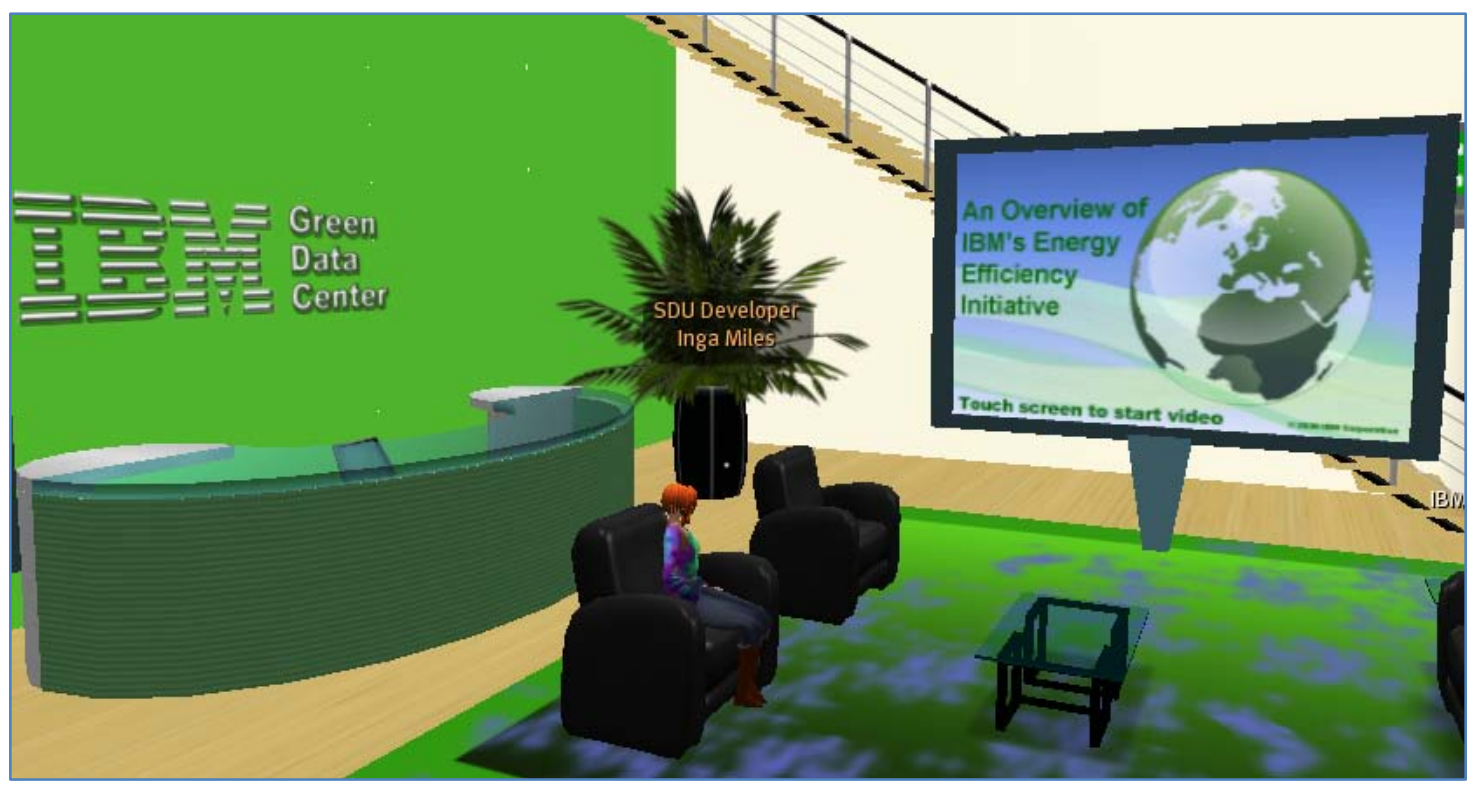

Figur 8. IBMs "Virtual Green Data Center".

Et andet interessant IBM sted er:

http://slurl.com/secondlife/IBM\%20Systems\%20EduCenter/128/128/31. Her demonstreres IBMs tekniske kunnen, og stedet kan især anbefales til de, der ikke er specielt teknisk-orienterede, da det visuelle spiller en stor rolle i formidlingen.

Anja optræder som avataren Ann Congrejo in-world og har haft sin gang i Second Life siden februar 2007. Anders er bag avataren Joe Cagney, der blev født i december 2006. Begge anvender IBMs lukkede og offentligt tilgængelige øer til kommunikation og samarbejde på tværs af landegrænser. IBM anvender desuden Second Life til træning af medarbejdere og til support af kunder.

\section{Bliv klog på læringspotentialet i Second Life}

Tony Breindal, Mediekonsulent på Det Nationale VidenCenter For e-Læring, er en guldmine af viden, når det gælder praktiske eksempler på, hvordan Second Life anvendes til at understøtte læreprocesser. Tony træffes in-world som Tonny Halderman, der blev født i februar 2007.

Tony har bidraget til artiklen med følgende beskrivelser, der peger på destinationer i Second Life af stor interesse for undervisere og uddannelsesinstitutioner.

\section{Canadian Border Crossing Simulation}

'Canadian border simulation at Loyalist College' fra april 2009 er et eksempel på, hvordan man meget konkret kan anvende Second Life under uddannelse og 
eksaminering. Loaylist Colege har etableret en virtuel udgave af en grænseovergang mellem USA og Canada og træner (rollespiller) de kommende grænsebetjentes opgaver:

\section{"The results of this project were both impressive and surprising to everyone involved. \\ Students participating in the Second Life simulation achieve a grade standing 28 percent higher than the previous class who did not utilize virtual worlds."}

http://secondlifegrid.net.s3.amazonaws.com/Docs/Second Life Loyalist EN.pdf http://wiki.vwbpe.org/index.php?title=Canadian Border Crossing Simulation http://www.youtube.com/watch?v=PCUWcpVPtMM

\section{SLENZ projektet}

Den New Zealand baserede uddannelsesgruppe for virtuelle verdner, Second Life Education New Zealand (SLENZ), har etableret et forskningsprojekt i Second Life for at gore det muligt for New Zealandske undervisere at planlægge og gennemføre mindst to pilotprojekter, der skal have til formål at afklare, hvordan uddannelser på New Zealand kan drage nytte af multi-user virtual environments (MUVEs), og hvordan dette gøres mest optimalt.

Disse faktorer blev set som støttetiltag for udvikling af projekter:

- Brugen of mentorer/hjælpere in-world for nye tutorer og studerende.

- Anvendelsen af professionelle MUVE udviklere/scriptere snarere end at forsøge at klæde undervisere/tutorer på til disse opgaver. Det blev observeret, at undervisning skal overlades til undervisere/facilitatorer, og bygning samt udvikling af faciliteter til MUVE udviklere og professionelle scriptere.

Projektet er godt dokumenteret og hjemmesiden er bestemt et besøg værd. http://slenz.wordpress.com/slenz-project/.

\section{Innovative Learning}

VIA University College, Campus Horsens v/Åge Staghøj har fået etableret øen 'Innovative Learning' i Second Life og vandt i sidste uge 'Den Nationale e-Læringspris 2009'. Læringsmiljøet er udført som en byggeplads og beregnet for sikkerheds- og miljøuddannelse af bl.a. tømrere, og der er etableret læringsobjekter indenfor kategorierne 'Nybyggeri', 'Nedbrydning', 'Arbejde i Jord \& Luft' og 'Vedligeholdelse / renovering'. 


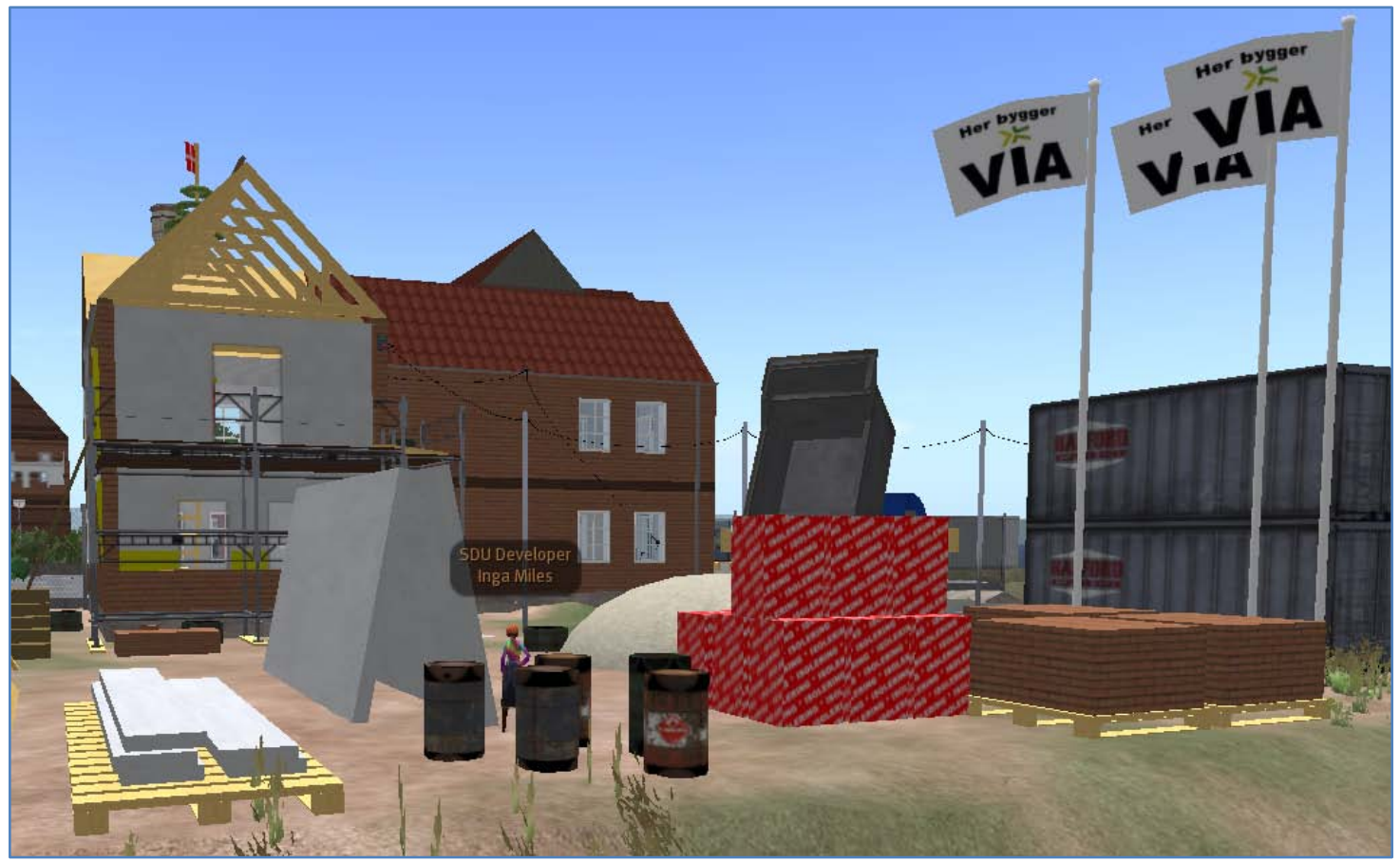

Figur 9. Byggeplads på Innovative Learning øen.

I læringsobjekterne er der indarbejdet så mange sikkerheds- og miljøproblematikker, at ingen endnu har været i stand til at danne sig det fulde overblik over dem.

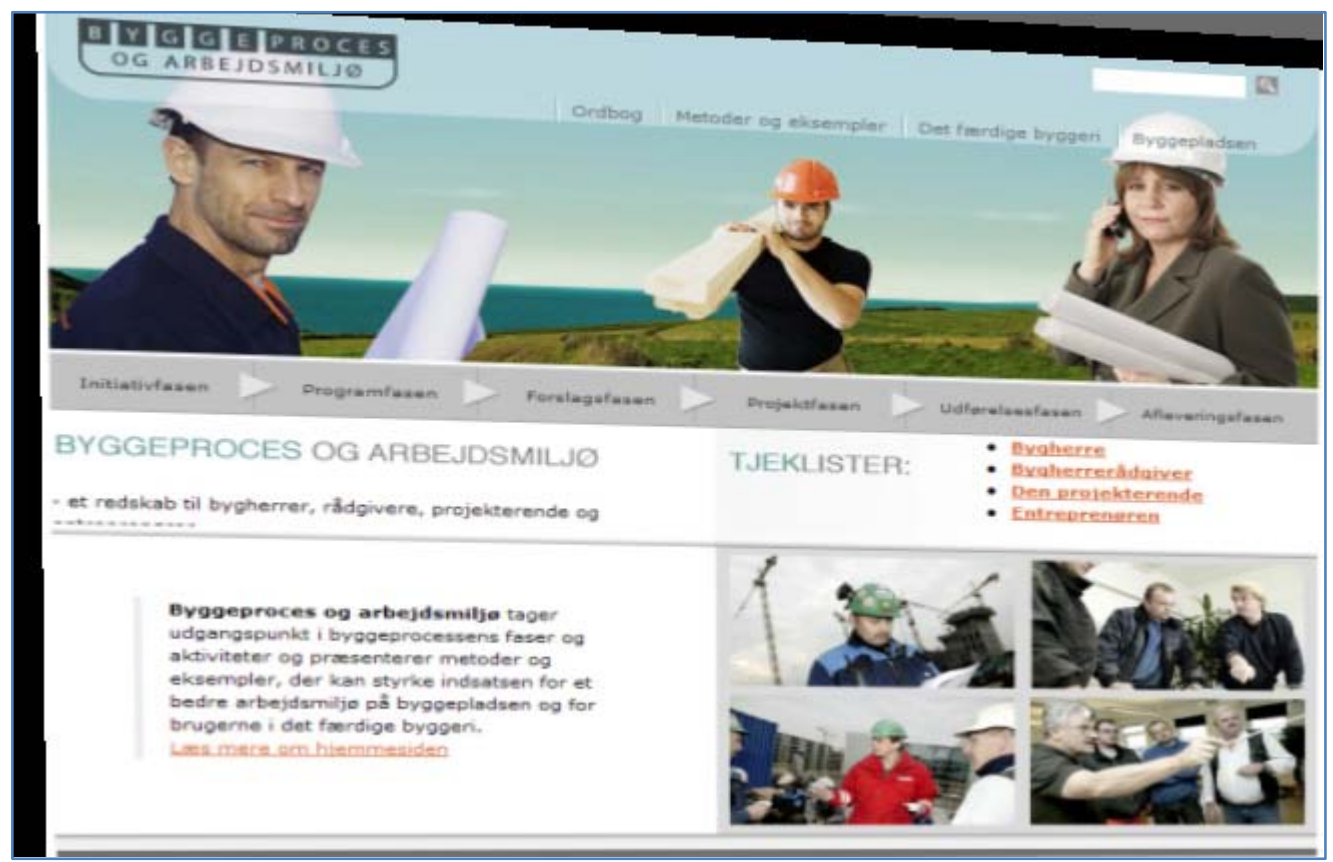

Figur 10. Planche om byggeprocess og arbejdsmiljø på Innovative Learning øen. 
Undervisningen foregår som tilstedeværelsesundervisning i tre dage, derefter 3 uger til refleksion, og så atter tre dage med tilstedeværelsesundervisning. Før og efter det seneste hold lærlinge, der har været igennem forløbet i Second Life, har der været foretaget spørgeskemaundersøgelse og den viser bl.a. at:

- $\quad 67 \%$ synes undervisningen har været mere spændende fordi man har anvendt Second Life (SL).

- $83 \%$ synes det har været decideret sjovt at anvende SL.

- $58 \%$ brugte SL under eksaminering om end det ikke var et krav.

- $75 \%$ anbefaler andre at bruge SL i undervisningen.

$\bullet$

Læringsmiljøet kan besøges her:

http://slurl.com/secondlife/Innovative\%20Learning/91/64/27.

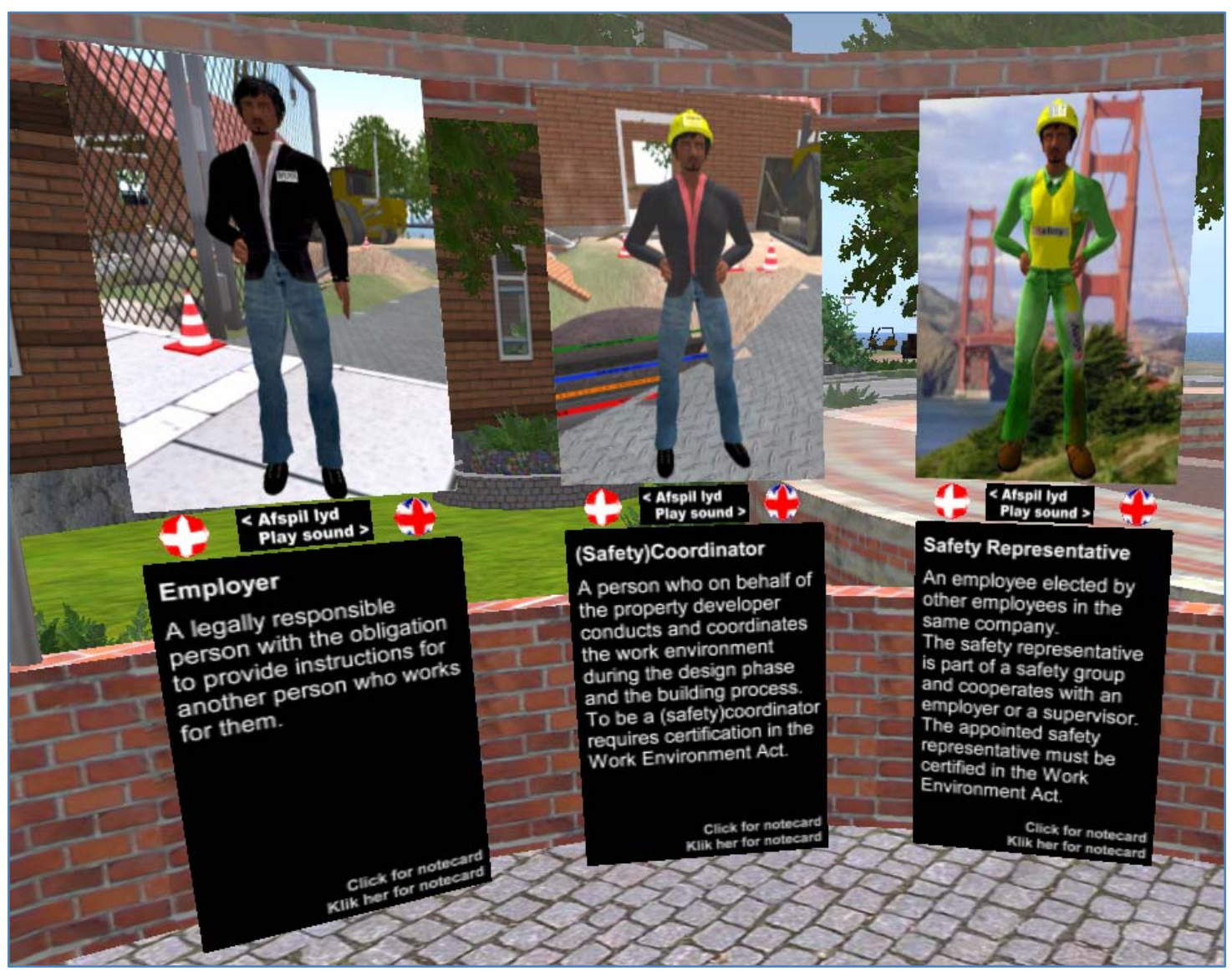

Figur 11. Avatar galleri - jobtitler og sikkerhed på jobbet - fra Innovative Learning øen. 


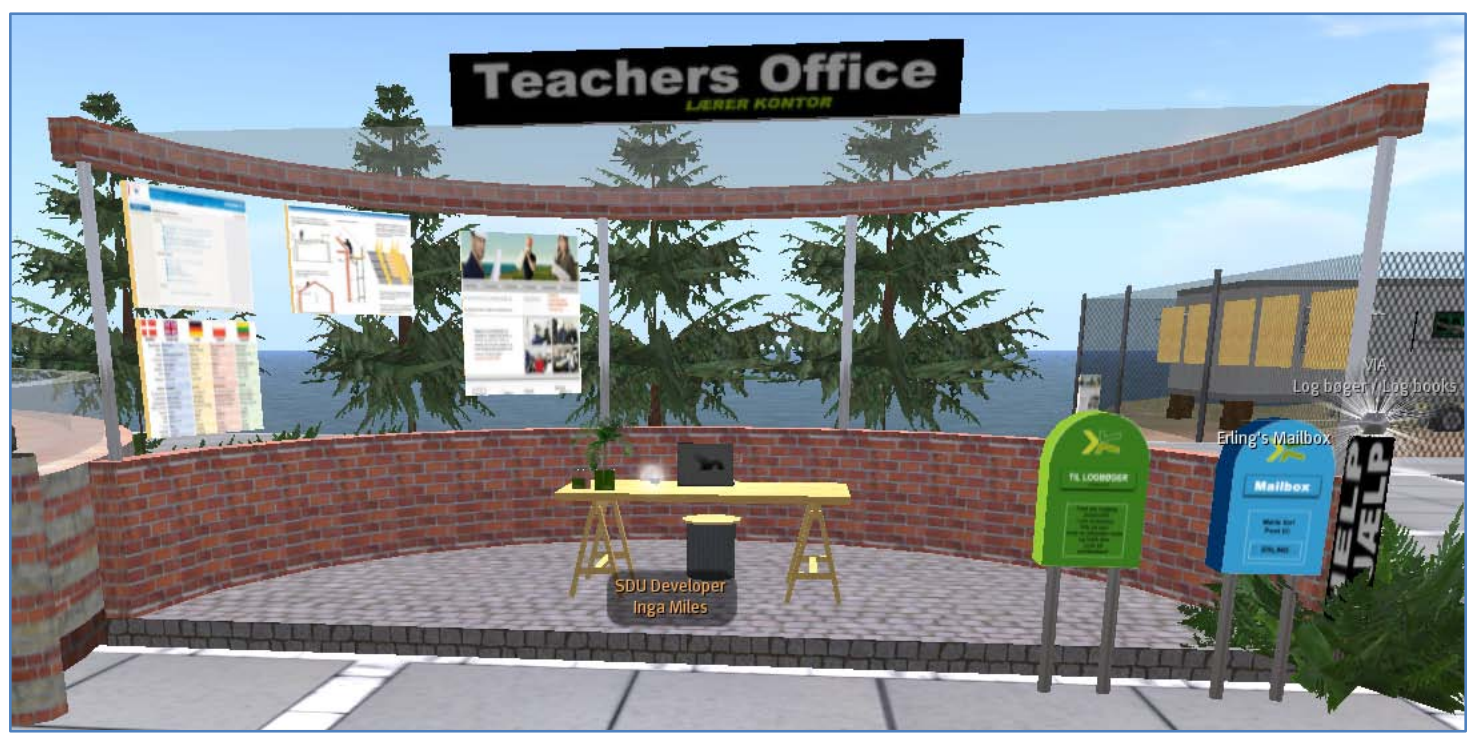

Figur 12. Det virtuelle lærerværelse med højt til loftet, postkasser mm.

Projektdeltagerne:

VIA University College, Åge Staghøj aka Age Contepomi (project owner) Lisbet Lücke Larsen aka HotLing Swindlehurst (design and building) Inge Knudsens aka Inge Qunhua (translations and paedagogic support) Flemming Nielsen aka Flemming Congrejo (programming) Klavs Lindequist aka Boo Schnyder (clothing and creating avatars) Tony Breindal aka Tonny Halderman (project management) (Breindal 2009)

\section{Tag på interaktiv studietur til Second Life}

Riv et par uger ud af kalenderen og unders $\emptyset$ g, hvordan interaktivitet er implementeret og udfolder sig i forskellige miljøer i Second Life. Fokus spænder vidt fra læring og vidensformidling over litteratur og teater til underholdning.

Det er PHD stipendiat Marianne Riis fra Aaborg Universitet, der har bidraget med nedenstående meget alsidige slurl samling (Riis 2009). Marianne underviser og forsker $\mathrm{i}$ og om Second Life, nærmere bestemt 3D-medieret problem-baseret undervisning og læring, og har som avataren Mariis Mills været til stede in-world siden marts 2007. Følg med på Mariannes blog 4 , hvor du også kan finde inspiration til din besøg i Second Life.

${ }^{4}$ http://milmariis.wordpress.com/. 
Marianne har i sine anbefalinger nedenfor lagt vægt på interaktive miljøer, hvor avataren har mulighed for at udforske det kropslige og tingslige aspekt ved at interagere med scriptede objekter. Det kan der komme både læring, leg og underholdning ud af.

\section{Biologi, genetik og anatomi omsat til konkret design - interaktive}

- BIOME - fokus på biologi - del af en hel naturvidenskabelig ø-gruppe med mange forskellige aktiviteter og ture http://slurl.com/secondlife/BIOME/184/143/30

- Genome Island - fokus på gentik http://slurl.com/secondlife/Genome/119/144/54

- OSU Medicine - fokus på anatomi - tag en tur inde i en testikel http://slurl.com/secondlife/OSU\%20Medicine/64/97/302

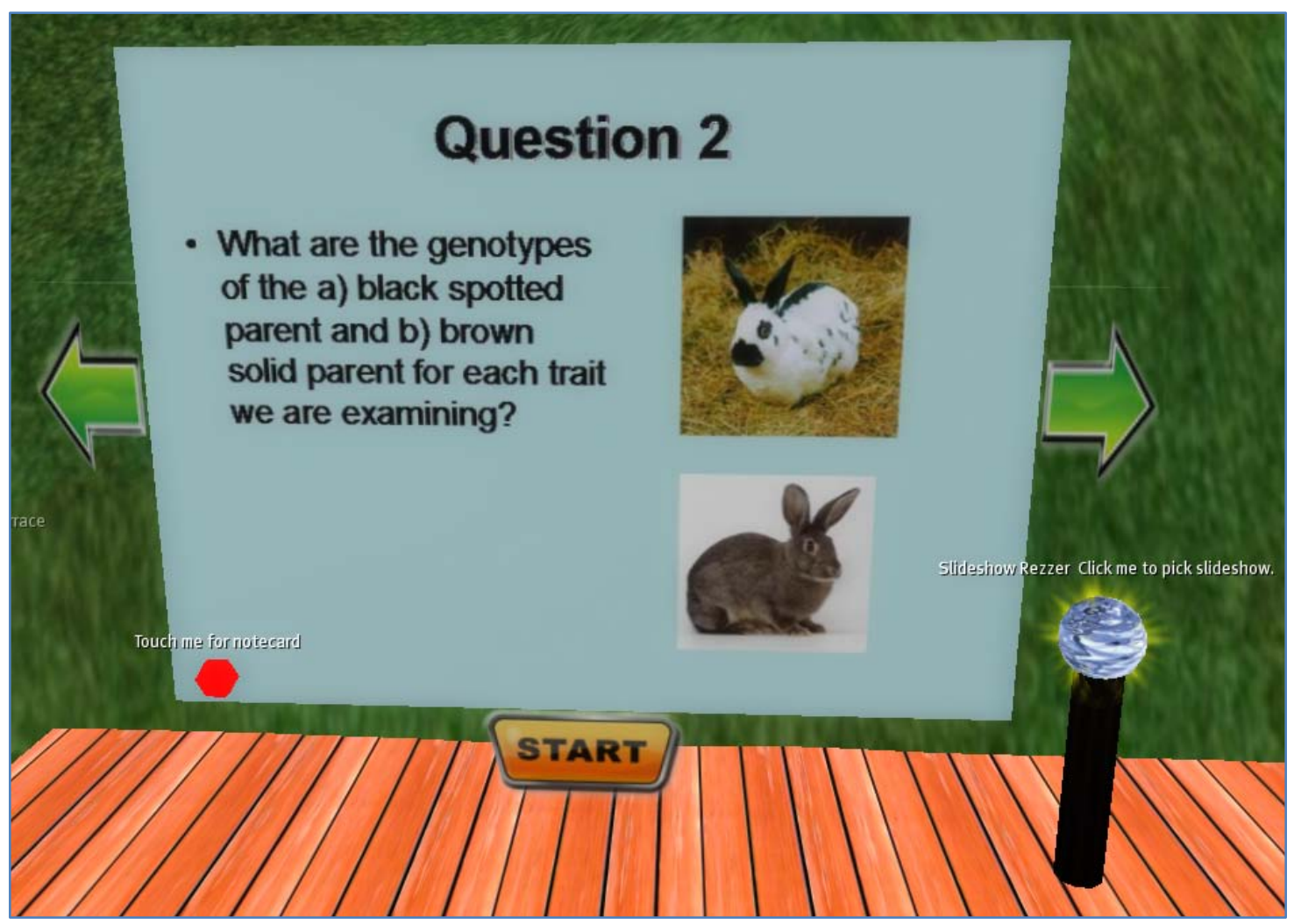

Figur 13. Slideshow på Genome Island. 


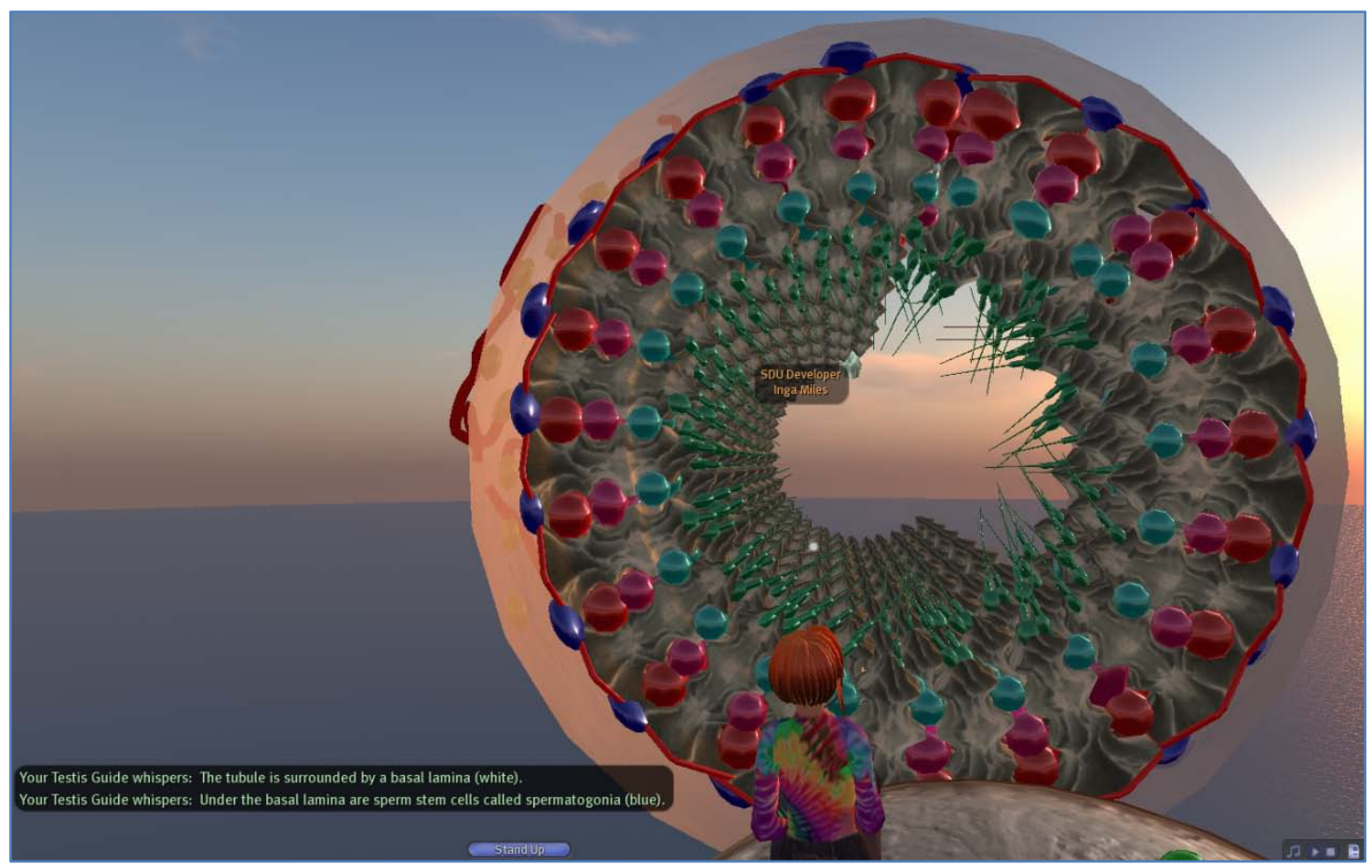

Figur 14. På tur gennem en testikel. OSU medicine.

\section{Teori omsat til konkret design - interaktive og gode til at fremme} diskussioner

- Koru Island - fokus på Gardner's MI (Multiple Intelligence) teori http://slurl.com/secondlife/Koru/39/224/22

- Teaching 4 - Iowa State - fokus på Bloom's taxonomi http://slurl.com/secondlife/Teaching\%204/211/176/25

- Teaching 4 - Iowa State - focus på Wenger's CoP teori http://slurl.com/secondlife/Teaching\%204/235/156/26

- U21 Metaphor Tour - en interativ flyvetur med focus på konstruktivisme http://slurl.com/secondlife/U21Global\%20Campus/230/143/44

- NED Island - fokus på Maslow's behovspyramide http://slurl.com/secondlife/NDE\%20Island/161/187/21 


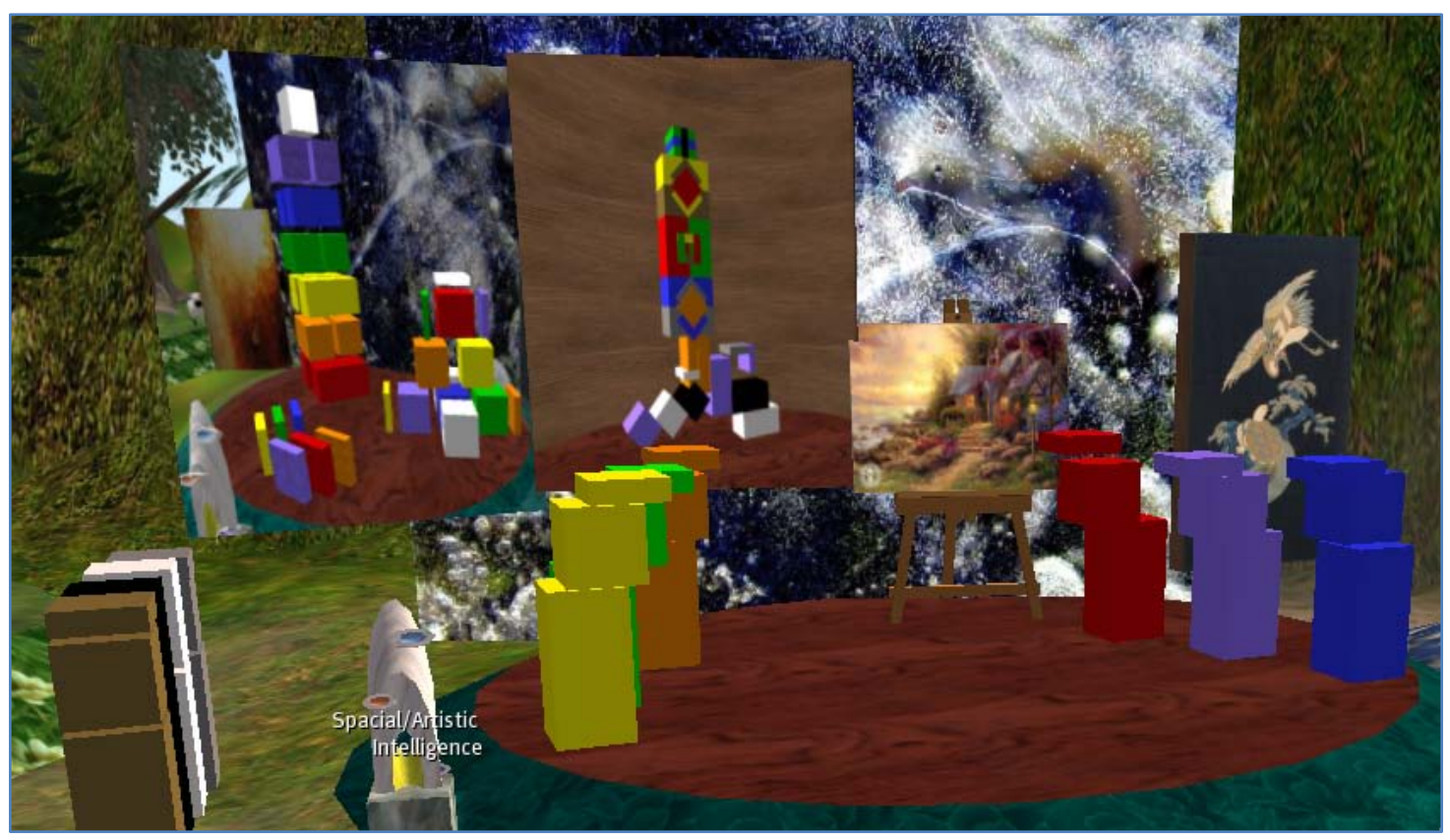

Figur 15. Koru Island med fokus på Howard Gardners Multiple Intelligences. Her "Spatial/Artistic" intelligens.

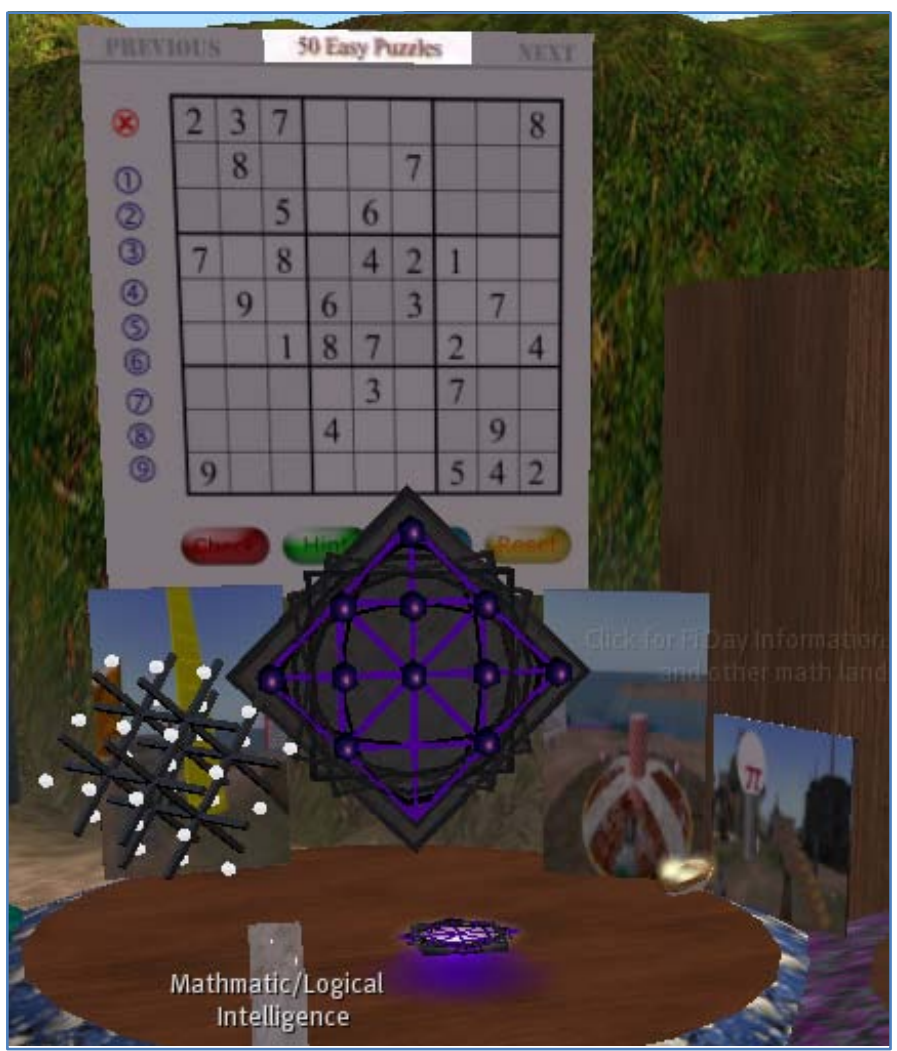

Figur 16. Matematisk / logisk intelligens på Koru Island. 


\section{Litteratur og teater}

- Ohio Edu - In the Sweet Bye and Bye - interaktiv poesi med lyd http://slurl.com/secondlife/OHIO\%20Edu/67/200/33

- Primtings - Globe Theatre - Shakespeare Company - live forestillinger http://slurl.com/secondlife/Skin\%20City/256/17/24

\section{Interaktive, underholdende ture}

- Virtual Africa - med ballon-tur

http://slurl.com/secondlife/Virtual\%20Africa/143/98/23

- Vassar Island - med flyvetur og genskabelse af The Sistine Chapel og VR rum (2 Link)

http://slurl.com/secondlife/Vassar/111/113/27

http://slurl.com/secondlife/Vassar/215/199/33

- Etopia Island - tag en togtur på øen, der sætter fokus på økologi http://slurl.com/secondlife/Etopia\%20Island/191/58/23

- La Movida - snup en flyvetur og nyd det smukke landskab http://slurl.com/secondlife/La\%20Movida/198/34/48

- Awa - Fjordsguilden Market - sejltur http://slurl.com/secondlife/Awa/161/141/26

- Rendervisions Isle - flyvetur i luftskib http://slurl.com/secondlife/Rendervisions\%20Isle/199/217/80

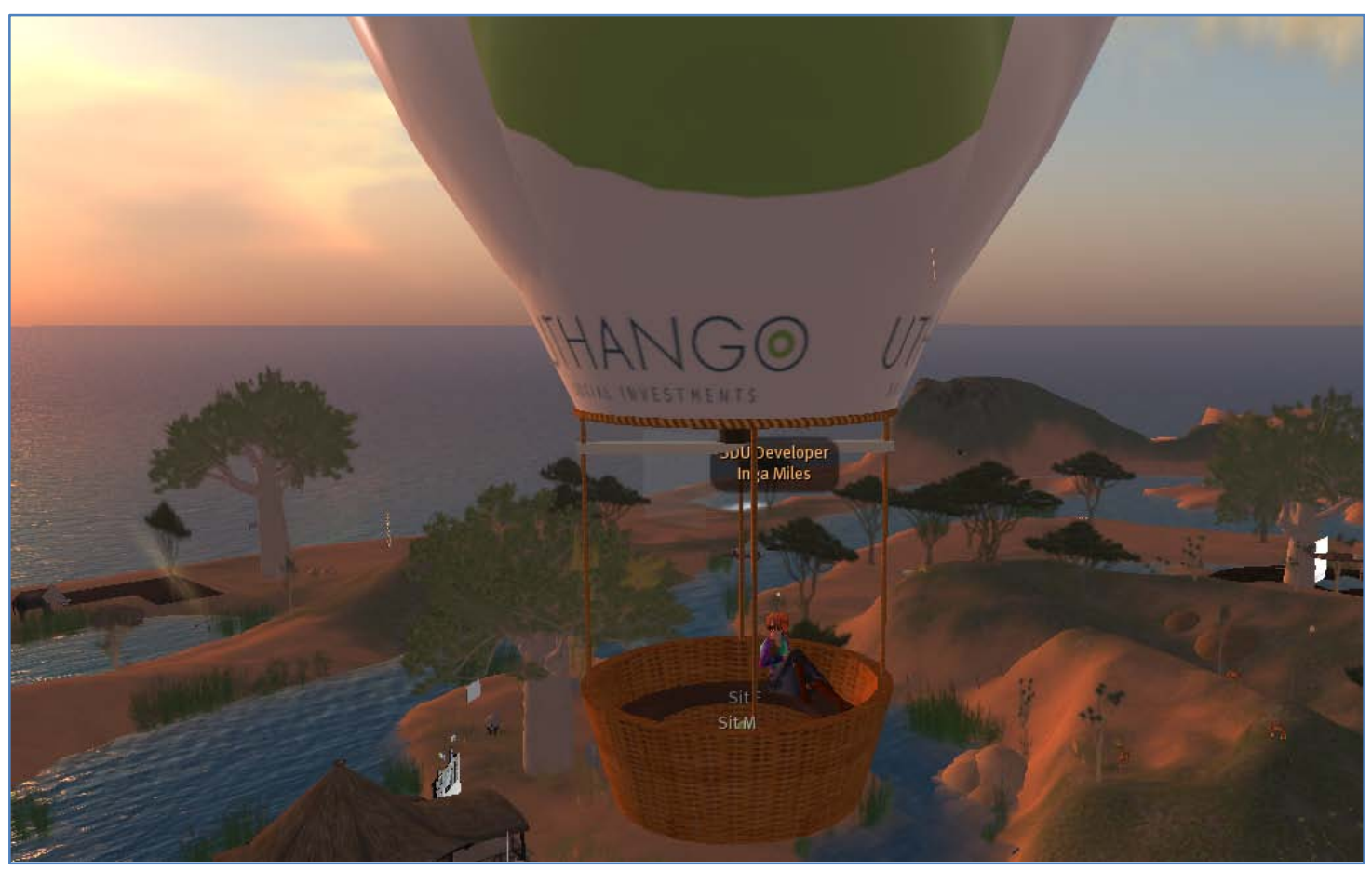

Figur 17. Ballontur - Virtual Africa. 


\section{Efteruddannelse i Second Life}

Hvorfor ikke få ny viden og nye kompetencer direkte fra sofaen hjemme i stuen. Sæt dig til rette og deltag i events og kurser online gennem Second Life.

Det er Signý Óskarsdóttir fra Bifröst Universitet på Island, der har bidraget med nedenstående slurls. Signý er Second Life projektleder og medlem af universitets elæringsteam. Hun har været til stede i Second Life siden februar 2009 som avataren Sole Lexenstar. I dette efterårssemester har Bifröst afholdt et kursus i Second Life for et hold på 50 Business Administration studerende. Bifröst vil nu udvikle og afholde yderligere kurser i Second Life i samarbejde med SDU. Second Life tænkes anvendt som platform for kollaborative læringsaktiviteter, hvor studerende fra Bifröst og SDU udover det faglige indhold også vil have mulighed for at opnå færdigheder og kompetencer indenfor 3D samarbejde, kommunikation og læring, der ruster dem til deres fremtidige arbejdsliv. Det er SDUs virtuelle campus i Second Life, der vil være udgangspunkt for forløbet.

Signý skriver:

"I do like the International Society for Technology in Education (ISTE). In there, I get a sense of Educational professionalism within SL and that is important. ISTE within SL works also as a hub for me which leads me to many topics relevant to the educational technology community. http://slurl.com/secondlife/ISTE\%20Island/111/46/30.

Mystic academy is new to me and therefore interesting. Mystic academy runs regular courses, discussions and various events. The environment is rich in colors and it is quite mystic. Some of the artifacts are inspiring and it is a treat to travel around. http://slurl.com/secondlife/Spirit\%20City/207/181/35.

I do like Bifrost (SDU's island in Second Life) for obvious reasons, I think when you get to know the surroundings of each landmark and the functions and possibilities you like it better. My favorite place at Bifrost is the garden. Contact the avatar Gunhild Soderstrom to get a guided tour of Percipitopia which is part of the Bifrost experience. http://slurl.com/secondlife/Bifrost/127/128/32." (Óskarsdottir 2009) 


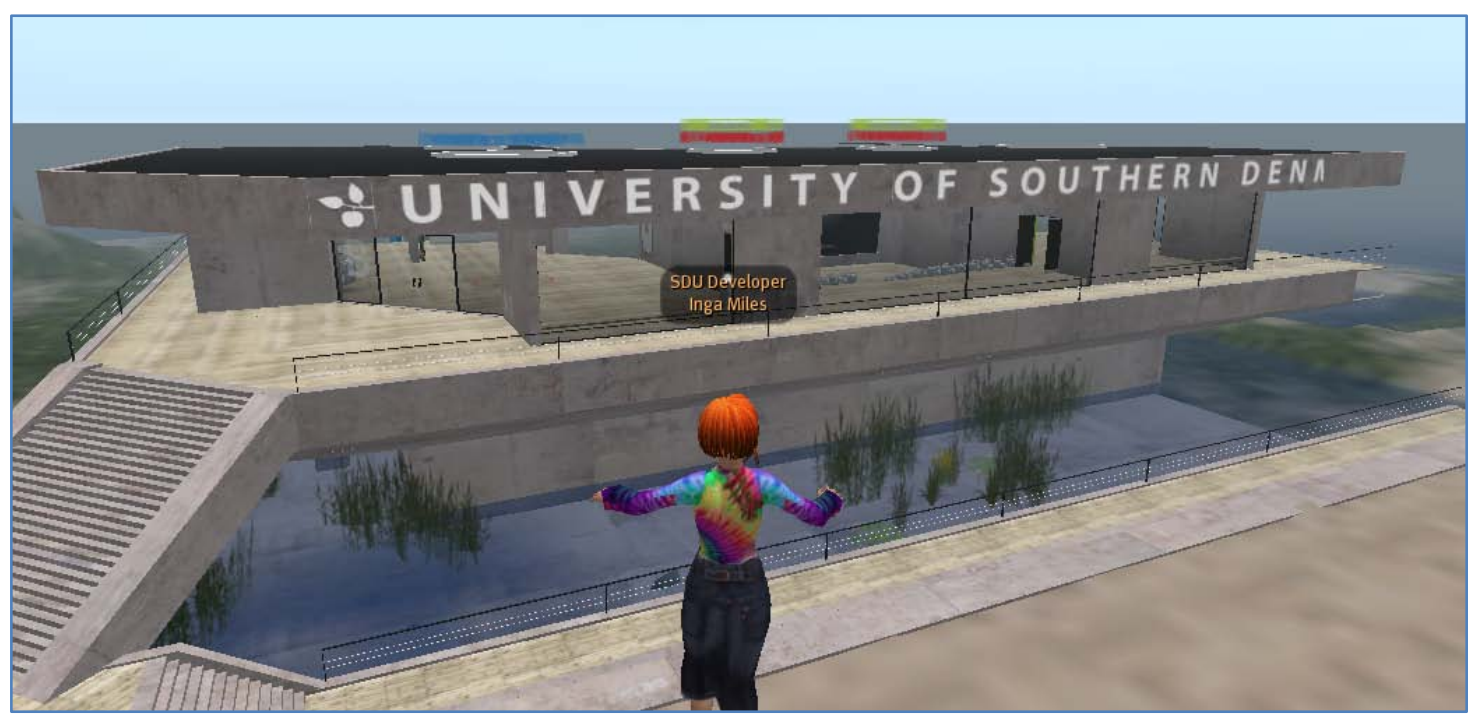

Figur 18. Vue over SDUs virtuelle campus.

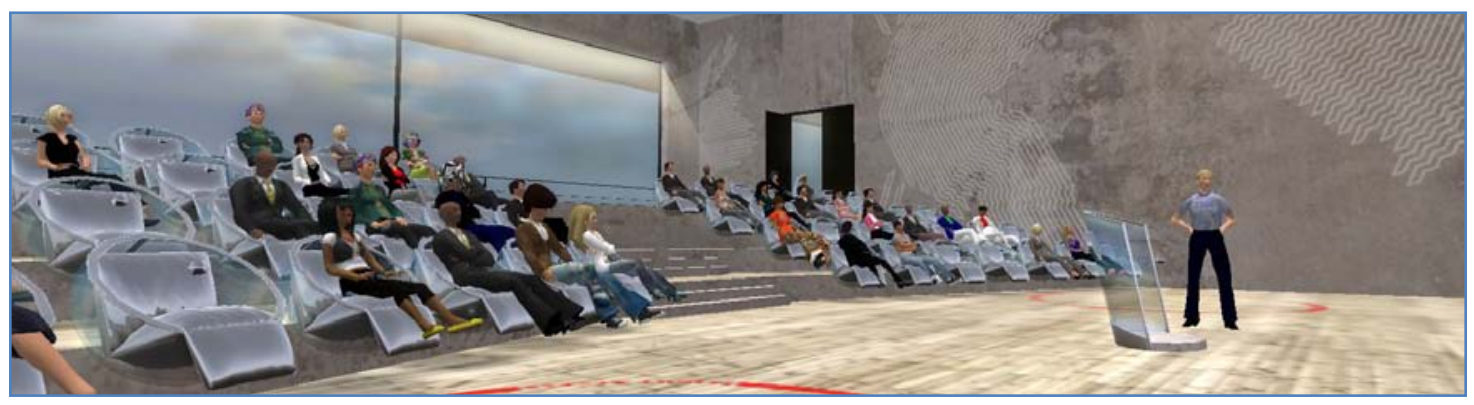

Figur 19. Forelæsning ved Anders Quitzau fra IBM i SDUs virtuelle auditorium.

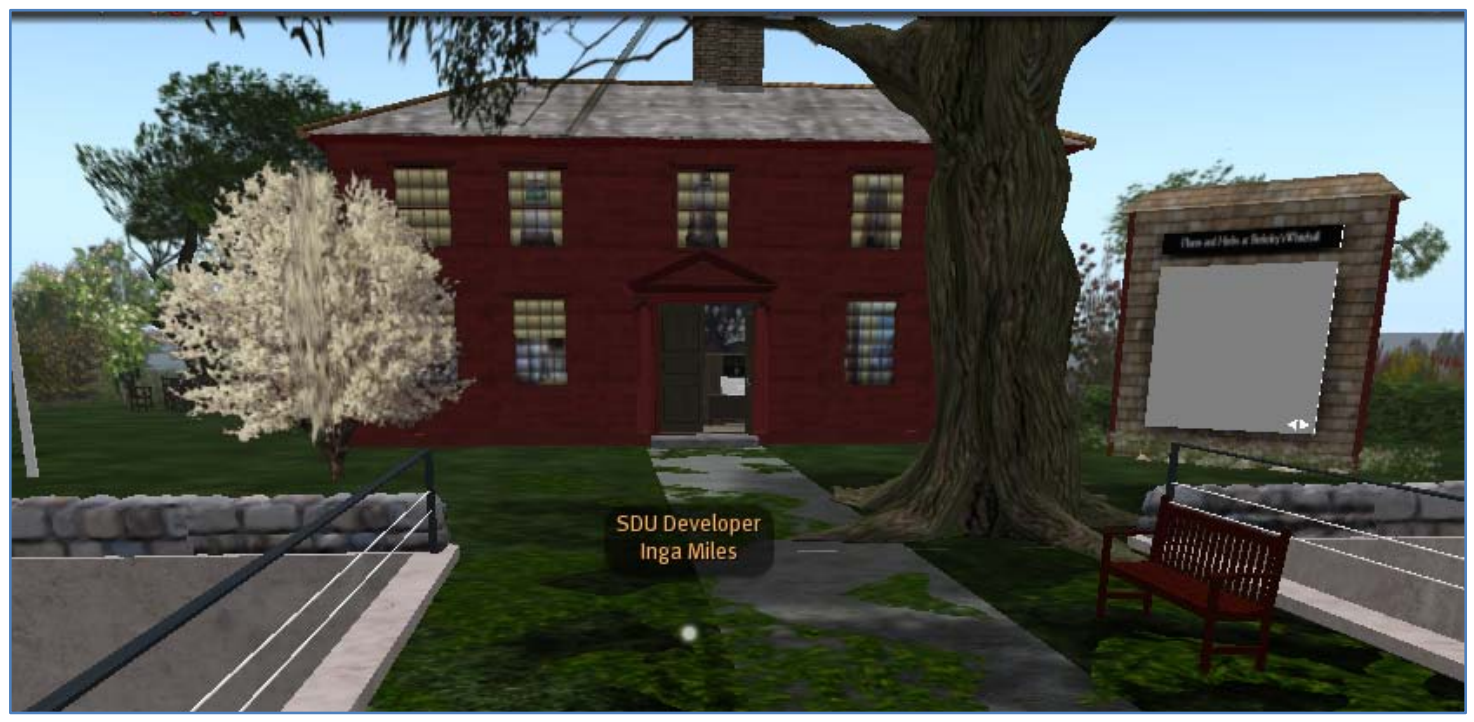

Figur 20. Whitehall. Den irske filosof George Berkeleys hjem på Rhode Island. 


\section{Scripting - Gør objekter levende}

I Second Life er der mulighed for at scripte objekter, man har konstrueret, sådan at de f.eks. bliver interaktive ${ }^{5}$. Steen Grønbæk, Mercantec ${ }^{6}$, arbejder selv med script programmering i SL og anbefaler dette sted in world:

http://slurl.com/secondlife/nimnam/232/73/601. Her findes et bibliotek, hvor man kan hente gratis scripts til brug i Second Life. På væggene hænger flere rækker med scripts, f.eks. en besøgstæller.

Mercantec er selv aktive i Second Life og ejer denne parcel:

http://slurl.com/secondlife/Learning\%20Island\%20Denmark/164/196/30

Steen fortæller:

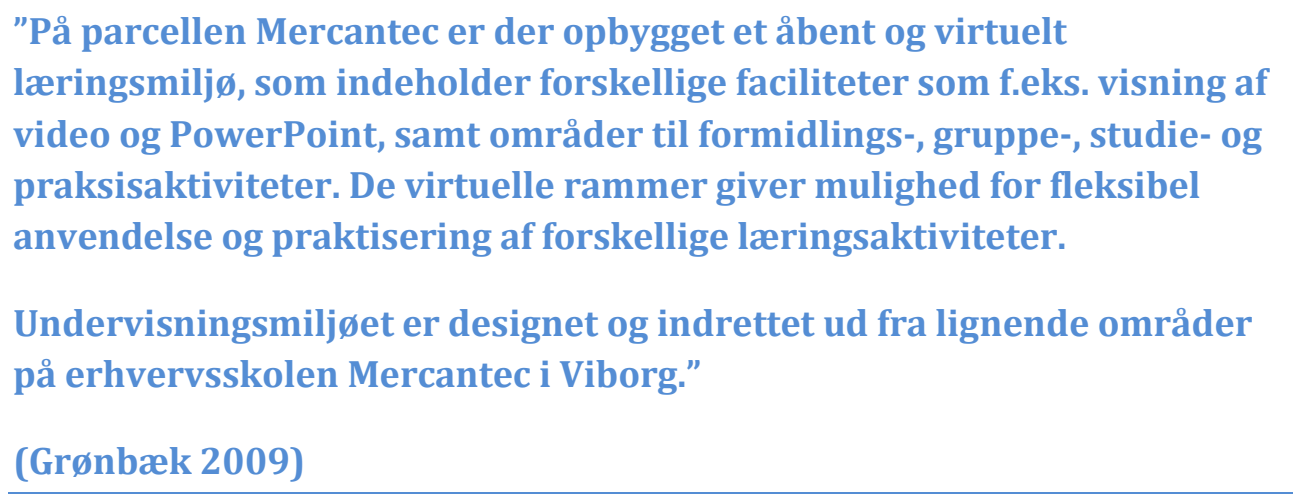

Steen gør også opmærksom på 3D muligheden i SL, der gør det muligt i undervisningssammenhænge at arbejde med og vise elementer og processer, som normalt er usynlige for det menneskelige øje. Her anbefaler han: http://slurl.com/secondlife/ACS/154/208/25.

"Navnet på denne parcel er: ACS - West Wing. ACS er en forkortelse for American Chemical Society. På denne parcel finder man bl.a. Chemical Landmarks Interactive Museum. Via animationer, plancher, slideshows og store svævende 3D opbygninger af molekyler, får man et indblik i baggrund og opbygning af eks. HIV-virus og penicillin."

(Grønbæk 2009)

${ }^{5}$ Se f.eks. denne scripting guide: http://www.instructables.com/id/Getting-started-inLSL-scripting-in-Second-Life/.

${ }^{6}$ Læs om Mercantec på denne webside http://www.mercantec.dk/Vis.aspx?job=W43091017\&id=79\&site=1. 


\section{Interaktive læringsspil, kunst, marsmænd og fortættet julestemning}

Inge Knudsen er ansat som underviser på Horsens Handelsskole, og har over 300 timers international undervisningserfaring i Second Life som avataren Inge Qunhua. Inge har desuden været med til at bygge flere læringsmiljøer in-world, senest CaseConnexion for syddanske sygeplejersker. Læs artiklen " CaseConnexion - udvikling af et virtuelt læringsmiljø til sygeplejestuderende" i dette nummer af LOM. Inge har været i Second Life siden marts 2007.

Inge anbefaler et besøg til disse steder i Second Life (Knudsen 2009), der byder på et spændende indblik i interaktive læringsspil, kunst, marsmænd og meget mere.

\section{Laring i Second Life}

Inge har konstrueret en række interaktive læringsspil til bl.a. fanget engelsk. På denne slurl kan du selv afprøve læringsspillene. Media Learning:

http://slurl.com/secondlife/Region\%20Denmark/149/199/22.

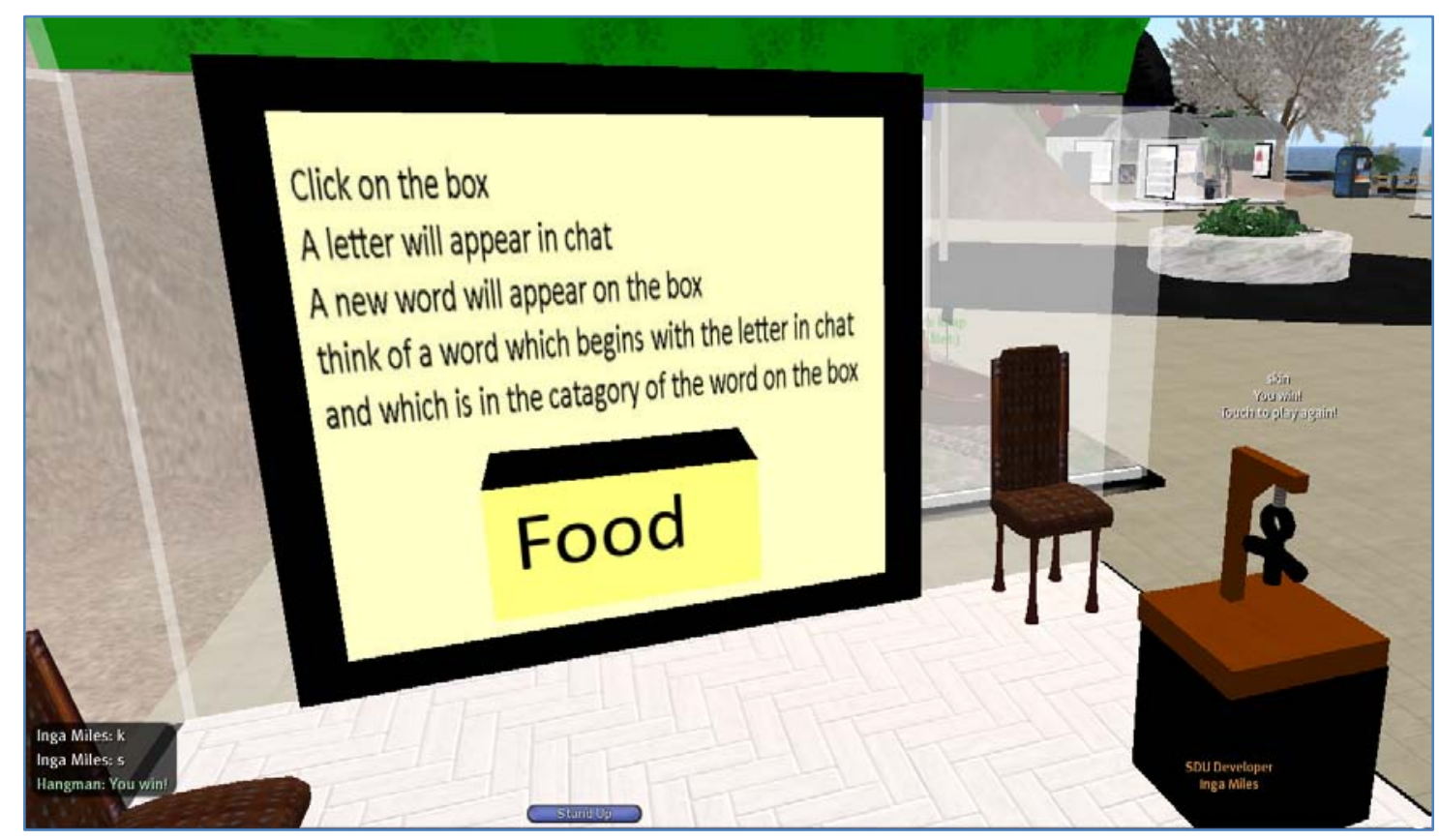

Figur 21. Medie Learning. Her spilles Hangman.

Tag også et kig på det virtuelle hospital, der anvendes af Sygeplejerske Uddannelsen Syddanmark. http://slurl.com/secondlife/CaseConnexion/51/146/22. Kontakt avataren Haunil Stine for yderligere information. 


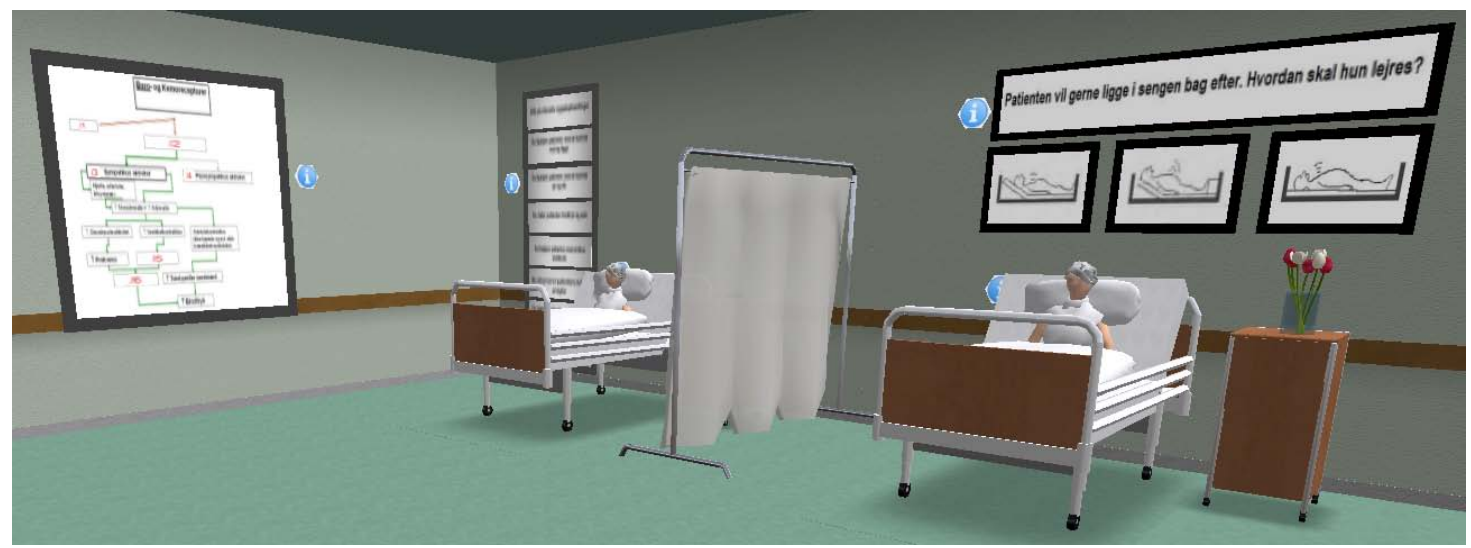

Figur 22. En stue på det virtuelle hospital. CaseConnexion.

\section{Kunst og kultur in world}

Besøg dette sted, der er baseret på byen Arles i Frankrig, hvor Van Gogh levede og malede ien periode. Du får her mulighed for at se de steder, der inspirerede Van Gogh til at gribe penslen. http://slurl.com/secondlife/Arles/111/166/21.

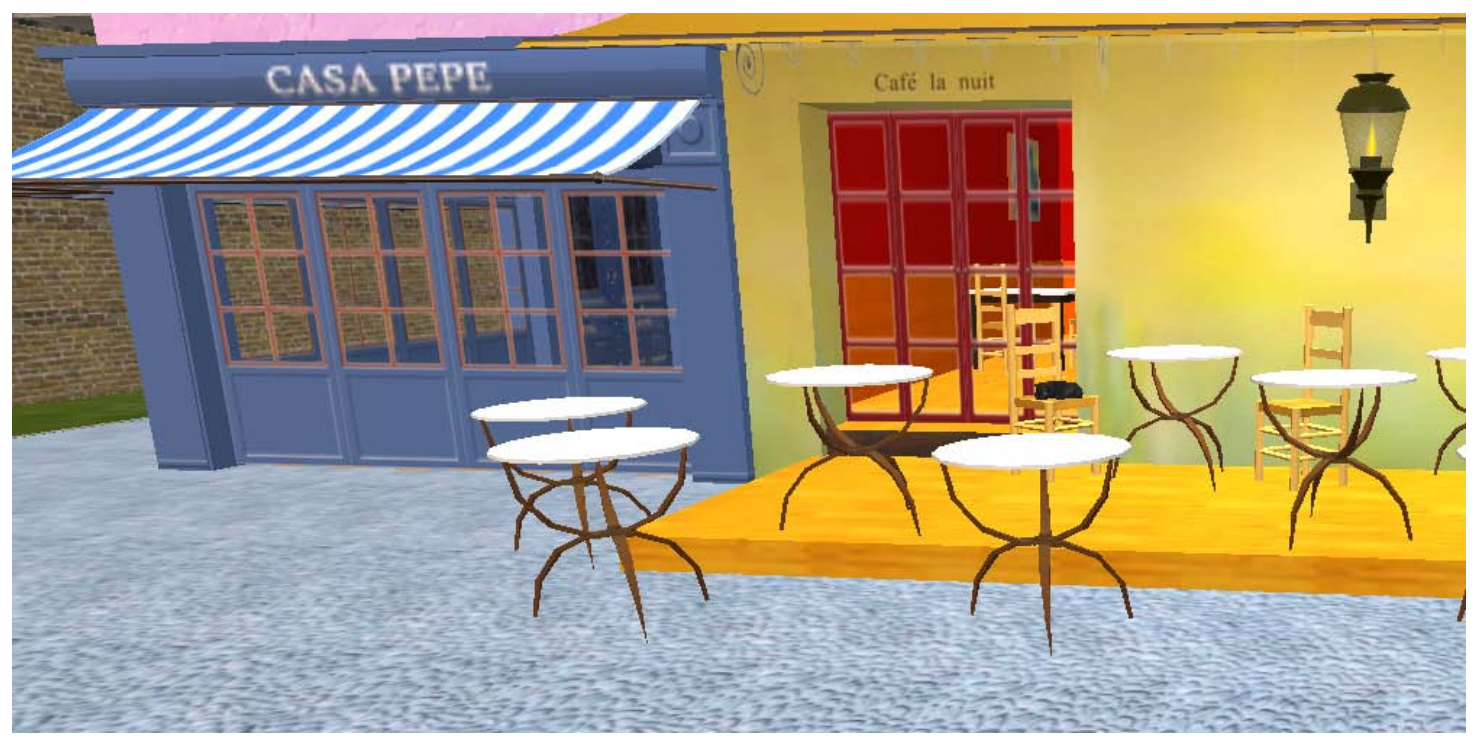

Figur 23. Arles. En stemning som den findes i Vincent Van Goghs malerier.

The pencil Factory @ The Port - Angrybeths Art Gallery:

http://slurl.com/secondlife/The\%20Port/31/66/26. Besøg dette fantastiske kunstgalleri, hvor det er tilladt at røre ved og ændre på de udstillede genstande. 


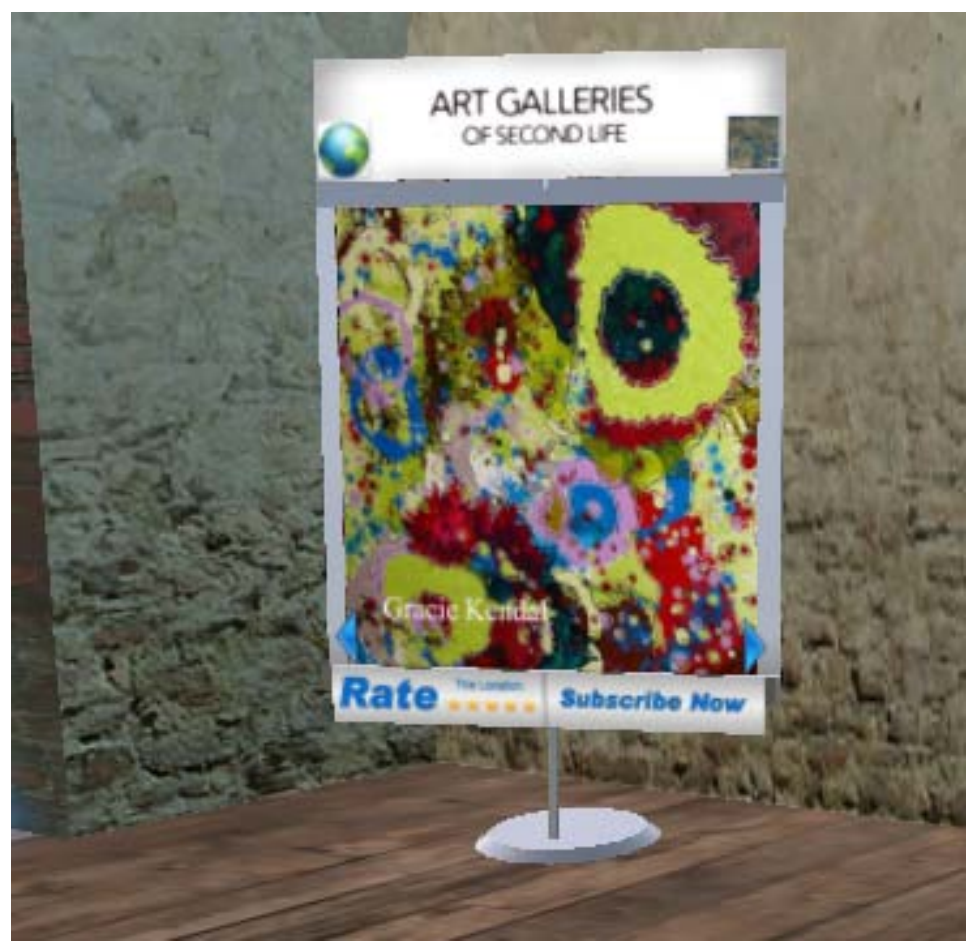

Figur 24. Et interaktivt kunstgalleri. Man må både se, røre og ændre.

Grønne mænd fra mars

Greenies Home er for de, der godt kan lide rumvæsener, snævre underjordiske gange mm. Besøg Greenies Home på:

http://slurl.com/secondlife/Greenies\%20Home\%20Rezzable/145/16/22.

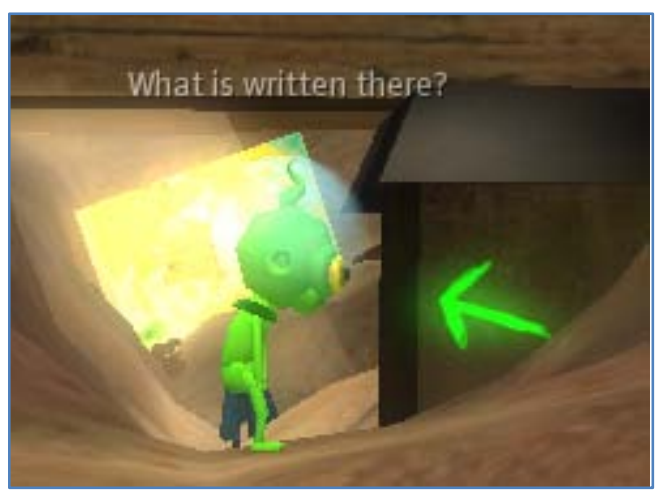

Figur 25. Marsmand fra Greenies Home

For nørder

Er du teknik nørd er dette noget for dig. En ægte gamezone, hvor Second Life spil testes. http://slurl.com/secondlife/Intoint/66/135/32. 


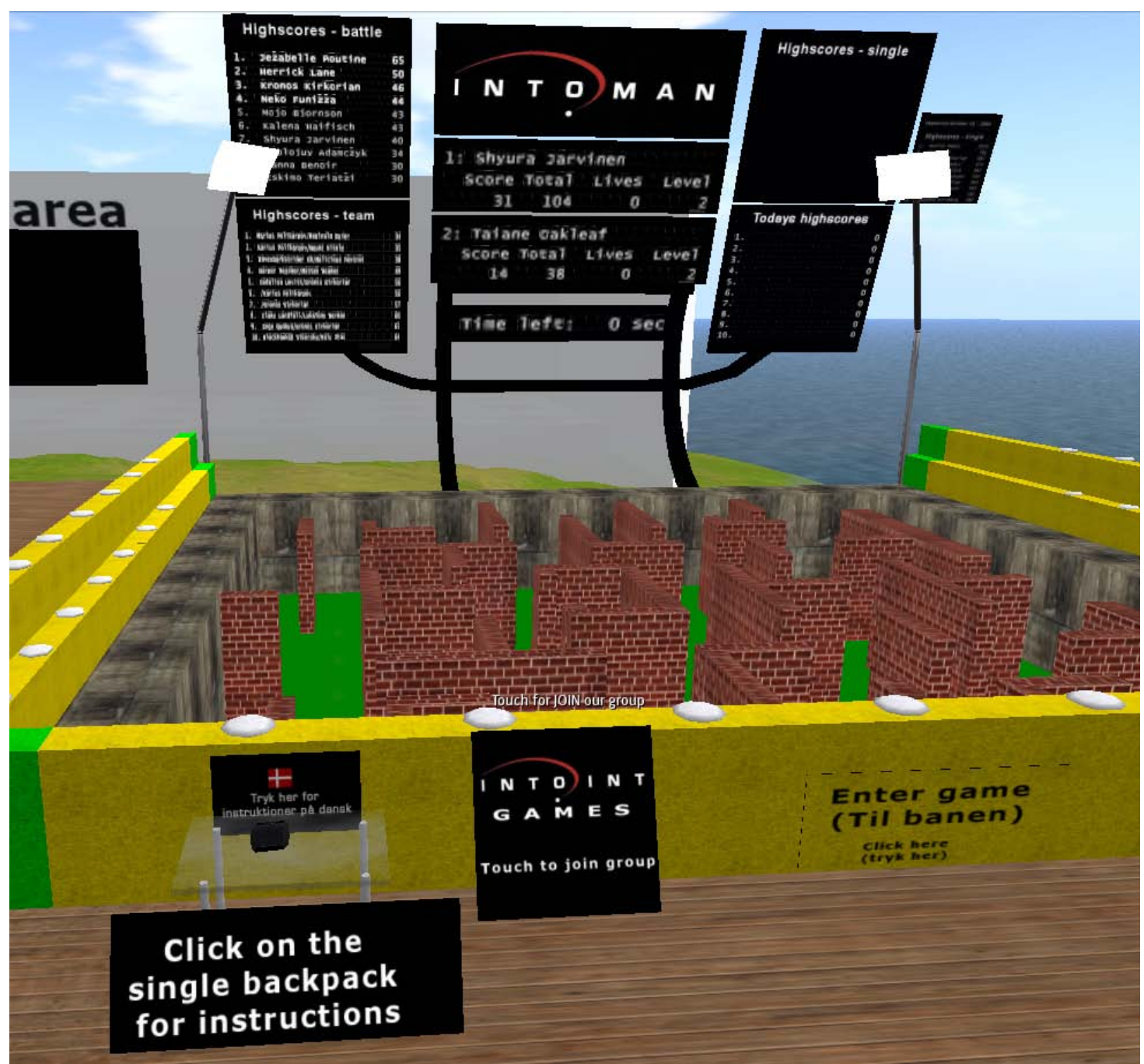

Figur 26. Game development area.

\section{Julestemning nu}

Winter Wonderland er til dig, der ikke kan få nok af Jul, snemænd og alt, hvad der hører sig til. Besøg stedet på http://slurl.com/secondlife/Dinky\%20World/15/120/21. Her kan du møde Julemanden og hans alfer, rensdyr og sågar engle. Kig dig omkring, nyd atmosfæren og køb julegaver og -dekorationer. God Jul. 


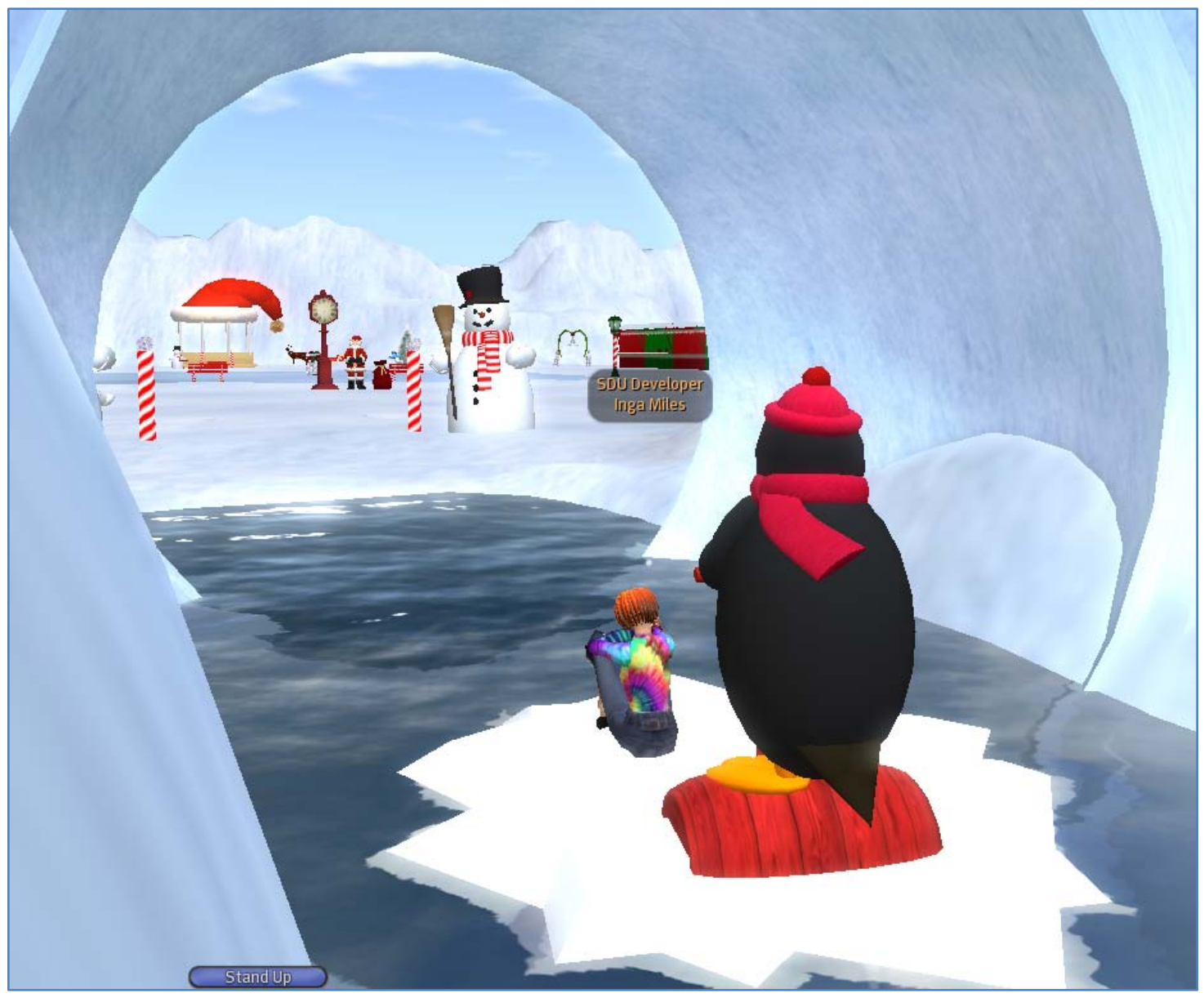

Figur 27. Her ankommer forfatteren til Winter Wonderland på en isflage dygtig styret af Pingu.

\section{Yderligere information}

Fremsøg selv interessante steder fra denne webside: http://maps.secondlife.com/.

Du ønskes en rigtig god rejse i Second Life.

\section{Referencer}

Breindal, T. (2009). Mail fra Tony Breindal, Mediekonsulent, Det Nationale VidenCenter for e-Læring til forfatteren tirsdag d. 10. november 2009.

Grønbæk, S. (2009). Mail fra Steen Grønbæk, Mercantec til forfatteren torsdag d. 12. november 2009. 
Morsi, M. (2006). Har din avatar tøj på? Udgivet på Kommunikationsforum onsdag d. 22. marts 2006. Hentet fra http://www.kommunikationsforum.dk/default.asp?articleid=12328 d. 8.november 2009.

Knudsen, I. (2009). Mails fra Inge Knudsen, underviser, Horsens Handelsskole til forfatteren mandag d. 9. november 2009.

Liboriussen, B. (2009). Lille Lise fik en Sackboy ${ }^{\mathrm{TM}}$ fin. I OnEdge. Nr. 2 Ting. Oktober 2009. Side 16-17. Odense: Knowledgelab.

Linden Lab (2009). About - The company. Hentet fra http://lindenlab.com/ d. 8. november 2009.

Nielsen, A. P. (2009). Mail fra Anja P. Nielsen, Life Cycle Manager, IBM DK Virtual Worlds til forfatteren tirsdag d. 10. november 2009.

Óskarsdóttir, S. (2009). Mail fra Signý Óskarsdóttir, Second Life project leder og medlem af e-læringsteam, Bifröst Universitet til forfatteren tirsdag d. 10. november 2009.

Riis, M. (2009). Mail fra Marianne Riis, PHD stipendiat, Aalborg Universitet til forfatteren tirsdag d. 11. november 2009.

Second Life Blogs. (2009). The Second Life Economy - Third Quarter 2009 in detail. Hentet fra https://blogs.secondlife.com/community/features/blog/2009/11/02/thesecond-life-economy--third-quarter-2009-in-detail d. 8. november 2009.

Second Life Wiki. (2008). SIM. Hentet fra http://wiki.secondlife.com/wiki/Sim d. 8. november 2009.

Second Life Wiki (Aug 2009). Voice Mentors: Getting Started with Voice. Hentet fra http://wiki.secondlife.com/wiki/Voice Mentors: Getting Started with Voice d. 12. november 2009.

Second Life Wiki (Sep 2009). What is a Holodeck. Hentet fra http://wiki.secondlife.com/wiki/Holodeck d. 8. november 2009.

Wikipedia. (2009). Metaverse. Hentet fra http://en.wikipedia.org/wiki/Metaverse d. 8. november 2009.

Wired. (2006). History. In Wired Magazine. Issue 14.10. Hentet fra http://www.wired.com/wired/archive/14.10/slfacts.html d. 8. november 2009. 